\title{
Evaluation and Optimization of Subsurface Irrigation (SDI) System: A review
}

\author{
${ }^{1}$ Abou Seeda M.A., ${ }^{3}$ Hammad S.A., ${ }^{1}$ Yassen A.A. and ${ }^{2}$ Abou El-Nour E.A. \\ ${ }^{1}$ Plant Nutrition Dept., National Research Centre, 33 El Buhouth St., 12622 Dokki, Giza, Egypt. \\ ${ }^{2}$ Fertilization Tech. Dept., National Research Centre, 33 El Buhouth St., 12622 Dokki, Giza, Egypt. \\ ${ }^{3}$ Soil and Water Dept. Agric. Mansoura University, Egypt.
}

Received: 22 June 2020/ Accepted 25 August 2020 / Publication date: 05 Sept. 2020

\begin{abstract}
Adapting an irrigation system is not clear duty and the number of available techniques can induce genuine doubt about which one would be the best. Still largely dominated by traditional irrigation methods, the agricultural sector is slowly living a turn in water management, to a more controlled and sustainable way of irrigating fields. Micro irrigation shows major benefit for saving water, improving yields and crop quality as well. Subsurface drip irrigation $(S D I)$ is a relatively new system technique that may give higher crop yields with less water than other irrigation systems. Proper site selection helps ensure optimum system performance and crop yield and minimizing expenses. The subsurface irrigation that ensure the availability of water for crops need to be developed for sustainable agriculture particularly, under climate changes. Irrigation is costly, so technologies need to be improved or newly developed, for sustainable agriculture use of precious water resources, and reducing labor and energy costs, which lead to higher production costs. Subsurface irrigation is a super water-saving system developed to irrigate upland crops through soil capillarity, Furthermore, considering, as an environmentally friendly, solar-powered automatic irrigation method with minimum energy consumption and operational costs. Micro irrigation systems along with their suitable applications, their installation, their advantages and limitations will help you consider the characteristics of your field, soil, crop, cropping system, and irrigation water resources as they apply to SDI.
\end{abstract}

Keywords: Subsurface irrigation, water management, climate changes, consumption and operational costs

\section{Introduction}

Subsurface drip irrigation $(S D I)$ is the application of water below the soil surface though emitters with discharge rates generally in the same range as drip irrigation. Thus, aside from the specific details pointed out, subsurface $(S D I)$ unit is simply all the drip irrigation network buried at a certain depth.

Subsurface textile irrigation (SSTI) is a technology designed specifically for subsurface in all from desert sands to heavy clays. Use of SSTI will significantly reduce the usage of water, fertilizer and herbicide. It will lower on-going operational costs and, if maintained properly, will last for decades. By delivering water and nutrients directly to the, plants are healthier and have a far greater yield. It is the only irrigation system that can safely use or without expensive treatment because water never reaches the surface. A typical subsurface textile irrigation system has an impermeable base layer a drip line running along that base, a layer of geotextile on top of the drip line and, finally, a narrow impermeable layer on top of the Photo. (1). Unlike standard, the spacing of emitters in the drip pipe is not critical as the geotextile moves the water along the fabric up to $2 \mathrm{~m}$ from the dripper.

The irrigation laterals are buried below the soil surface typically between 13 to 20 inches, depending on soil and crop type, climate, and management practices, etc .Burying drip lines underground minimizes surface soil evaporation besides there is no runoff. SDI provides the opportunity to supply proper amount of crop of crop water and nutrients needs directly the crop root zone. Crops can be spoon-fed water and nutrients. The spoon-fed characteristic of the SDI system has a great potential to minimize or eliminate the movement of water and nutrients below the crop rootzone when properly managed. SDI system, the irrigation water is filtered at the filter and control station before application to the field through the drip laterals. When properly managed, irrigation application losses (wind drift, soil evaporation, deep percolation and runoff) with the SDI are significantly lower as compared to the other irrigation system. Subsurface drip irrigation applies water and nutrients directly to the crop root zone through buried polyethylene. Drip lines have varying diameters and thickness in order to maintain acceptable irrigation uniformity for different field lengths. Smaller Corresponding Author: Abou Seeda M.A., Plant Nutrition Dept., National Research Centre, 33 El Buhouth St., 12622 Dokki, Giza, Egypt. E-mail:mabouseeda@gmail.com 
diameter drip lines are used when short lateral lengths are required. As lateral length increases, a larger diameter drip line must be selected to maintain adequate irrigation uniformity. The thickness of drip line wall is directly related to its durability. Drip lines with small thicknesses are mainly used for temporary installations, which will be discarded after a short time, such as when being used to irrigate high value crops. Thicker driplines are used for permanent installation. The thicker drip lines can also withstand higher operating pressures. The coast of the drip line is directly related to both diameter and thickness. Small holes called emitters are usually spaced every 8 to 24 inches along the length of drip line. During irrigation, pressure forces the water out of the emitters drop by drop. Once the water is in the soil, its movement and wetting pattern will depend on the initial soil water status, flow rate, and physical characteristics of the soil. In a fine textured soil, water will tend to move laterally and upward, as compared with a sandy soil where water tends to moves mainly downward. The amount of water that can be delivered through a drip system depends on drip line diameter and spacing, emitter spacing, operating pressure, emitter size, and emitter design. Varity of drip lines are now available from different manufactures to fit the specific design requirements for different soil, crops and weather condition.
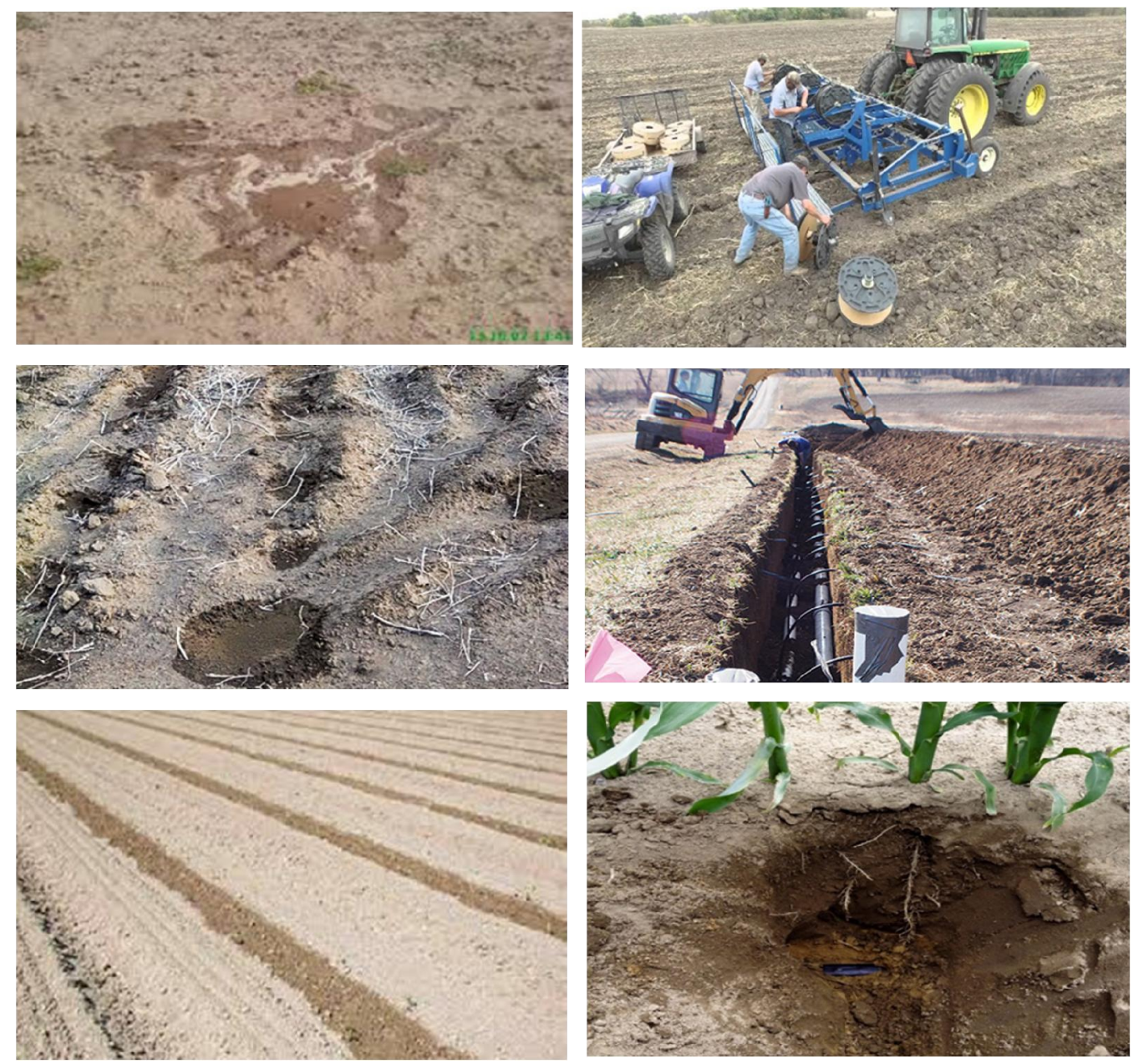

Photos 1: Illustrates the installation of lateral of subsurface drip irrigation $(S D I)$, showing wetted soil surface above the laterals subsurface drip irrigation (SDI) supplies water directly to the crop root zone via buried polyethylene drip line and emitters. 


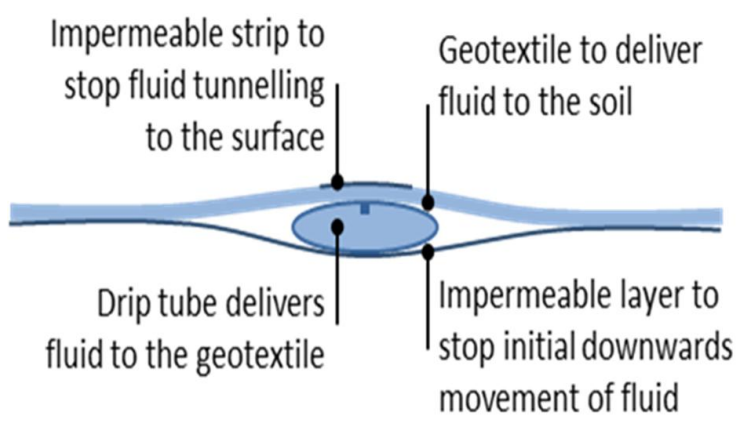

Fig. 1: Represents, diagram SSTI is installed $30-50 \mathrm{~cm}$ below the surface for agricultural applications.

There is a wide variety of plants irrigated with SDI such as herbaceous crops (lettuce, celery, asparagus and garlic), woody crops (citrus, apple trees and olive trees) and others such as alfalfa, corn, cotton, grass, pepper, broccoli, melon, onion, potato, tomato, etc. The efficiency of subsurface drip irrigation SDI could be similar to drip irrigation but it uses less water. It could save up to $25 \%-50 \%$ of water as compared to surface irrigation. The specific characteristics of SDI will be presented and some criteria for its design and management will be highlighted Fig. (1). Rain fed agriculture occupies $80 \%$ of the world's agricultural lands and currently contributes $60 \%$ of the world's food production (FAO, 2011). However, the sustainability of rain fed agriculture in some regions is in peril as it is gravely threatened by climate change IPCC (2014), as a result of which not only food security Webber et al., (2014) but also the social structure Roudier et al., (2011) in many countries is in danger. Since water availability directly influences the efficient use of all other inputs, better water availability in turn ensures optimum yields from a given combination of inputs (Sharma et al., 2015). Therefore, emerging irrigation technologies ideally should be developed to enhance crop water availability in order to make agricultural practices sustainable in long run. Shifting from rain fed to irrigated agriculture or from lowefficiency to high-efficiency irrigation methods offers important remedial measures against a changing climate; adaptation could be inhibited by the reluctance of farmers to adopt practices that elevate operational costs, such as high-efficiency irrigation methods. Therefore, new irrigation technologies would be more likely to be adopted if they were designed to save precious water resources, labor and energy costs as low as possible. Various irrigation methods, such as surface, subsurface, sprinkler, and drip irrigation, can be selected. Ali (2011) stated that, selected method depend on physical, economic, and social factors, and in turn determines the efficiency of resource use, economic viability, and sustainability of upland farming systems . In the past, surface irrigation methods such as basins, borders, and furrows have been used to irrigate upland crops in many regions of the world, due to their simplicity and low cost. In surface irrigation methods, water flows over the entire field or along furrows by gravity. When flowing, water infiltrates the soil and provides irrigation water to the root zone of crops.

The uniformity of distribution and application efficiency depends on the degree of land leveling; therefore, it consumes high labor costs for land preparation (Van Lier et al., 1999; Strelkoff et al., 2007). With increasing energy and labor costs, however, and with increasing demand for diminishing water resources, surface irrigation has been replaced to some extent by subsurface, sprinkler, or drip irrigation methods. Surface irrigation still is the major irrigation method used to irrigate upland crops worldwide. Drip and sprinkler irrigation methods were developed for high-frequency irrigation of crops by means of a systematically installed pipe network and emitting devices (Ali 2011; Martin et al., 2007. In drip and sprinkler systems, water is supplied under pressure and water often passes through various types of filters depending on the type of irrigation system and water source (Martin et al., 2007). Sprinkler irrigation including solid sets, periodic move or continuous move systems, traveling guns, and boom sprinkler systems has advantages over surface irrigation in terms of its high efficiency of water application, better of fertilizer application, and high resultant crop yields (Mikkelsen et al., 2015). However, it also has some drawbacks such as high setup costs, high operational costs due to its high energy and maintenance requirements, and its tendency to be adversely affected by wind conditions (Van Lier et al., 1999). Drip irrigation (irrigation systems that are designed to slowly apply water to individual points) on the other hand, overcomes some of these drawbacks by way of low energy 
requirements and not being affected by wind. It has distinctive water and energy saving features while supporting the agronomy of crops in addressing the challenges faced in irrigated agriculture (Evans et al., 2007). The major drawback of drip irrigation systems is the clogging of emitters, which leads to poor performance and calls for frequent maintenance. Further, damage by weathering and farm machinery partly explains why such an appealing technology remains unpopular among farmers (Ali 2011; Van Lier et al., 1999; Mikkelsen et al., 2015).

Although subsurface drip irrigation systems have been developed to overcome the prevailing practical issues of drip irrigation, they have not performed as expected, since they further aggravate the problem of poor water distribution efficiency due to emitter clogging (Payero et al., 2007; Li, et al., 2008). Accordingly, new irrigation methods are being developed to irrigate upland crops that aim to use water more efficiently and effectively with minimizing costs to improve profitability and sustainability.

\section{History of subsurface irrigation}

First known reference of a subsurface irrigation comes from China more than 2000 years ago (Payero et al., 2007; Li, et al., 2008). Where clay vessels were buried in the soil and filled with water. The water moved slowly across the soil wetting the plants' roots. SDI, as we know it nowadays, developed around 1959 in the US Van Lier et al., (1999), especially in California and Hawaii, as a drip irrigation variation. In the 60s, SDI laterals consisted of polyethylene PE or polyvinyl chloride PVC plastic pipes with punched holes or with punched emitters. These systems used to work at low pressures, depending on water quality and filtration systems. By the 70s, this method extended to crops as citrus, sugar cane, pineapple, cotton, fruit trees, corn, potato, grass and avocado. Its main disadvantages were the difficult maintenance, the low water application uniformity and the emitters clogging due to, mainly, oxide and soil particles. Alternatively, the equipment for SDI installation in the field developed Van Lier et al., (1999), and the fertilizers' injection with the irrigation systems started in Israel (Payero et al., 2007). Further, the quality of commercial emitters and laterals improved and SDI gained respect over other irrigation methods mainly due to the decrease of clogging. At the beginning of the $80 \mathrm{~s}$, factors such as: the reduction of the costs in pipes and emitters, the improvement of fertilizers application and the maintenance of field units for several years promoted the interest in SDI.

\section{Subsurface drip irrigation in the world}

There is a general agreement about the spread of SDI however, it is difficult to obtain data to confirm this trend since the surface irrigated with SDI is counted as a drip irrigation in most surveys. In the US, the USDA Farm and Ranch Irrigation Survey (FAO, 2011), indicates that SDI comprises only about $27 \%$ of the land area devoted to drip and subsurface drip irrigation. Nonetheless, this percentage is continuously increasing over drip irrigation as farmers substitute their conventional drip irrigation methods by SDI systems. If this framework continues in the future, SDI would still have a potential increase.

In underdeveloped countries, there are many references about the so-called low-cost SDI with rudimentary laterals and low emitter pressures that highlight even more, the SDI potential increase. Likewise, the savings on water and energy enhance this.

\section{Management of micro irrigation in arid and semiarid regions}

Meanwhile, judicious water use, long-term sustainability and increasing efficiency, as well as improving the yield to water consumption ratio become major priorities to overcome the limited availability of irrigation water in arid and semiarid regions. Micro irrigation technology is considered as a higher water saving option that can be applied in these regions with alternative cropping options. Micro irrigation is the slow application of water on, above or below the soil surface-by-surface drip, subsurface drip, bubbler and micro sprinkler system (Lamm et al., 2007). Water is applied as discrete or continuous drips (also called trickle), tiny stream, or miniature spray trough emitters or applicators placed along a water delivery line adjacent to the plant row (ASAE, 2001). In some parts of the world, micro irrigation is called localized irrigation to emphasize that only part of the soil volume is wetted. Micro irrigation is usually characterized by the following features: (i) water is applied at low rates; (ii) water is applied over long periods; (iii) water is applied at frequent intervals; (vi) water is applied near or into the root zone; (v) water is applied by a low-pressure delivery system; and (vi) water is routinely used to transport fertilizers and other agricultural chemicals (Lamm et al., 2007). 
Several benefits of micro irrigation are reported by many investigators such as (a) increased water use efficiency; (b) improved crop yields and quality; (c) reduced non beneficial use by decreasing surface evaporation and elimination of irrigation run off from sloping fields or hillsides; (d) reduced deep percolation; (e) improved fertilizer and other chemical applications with minimized leaching and run off of the chemicals. Despite observed successes and possible advantages, several shortcomings have been encountered with the economics and mechanics of applying water with micro irrigation systems for some soils, water qualities and environmental conditions. The disadvantages include; (1) expensive initial and maintenance costs; (2) require expert and advanced skill to install the irrigation network, (3) potential emitter clogging due to root and solid particles intrusions; (4) salt accumulation near plants when high salinity water is used in arid regions (Lamm et al., 2007). The continuous use of micro irrigation in arid and semi-arid environments inevitably leads to water table variations, and often to problems of water logging and salinization. Nitrate resulting eight from nitrogen fertilizers used in agriculture is a widespread contaminant of groundwater and causes adverse effects on the human's health, animals, and the ecosystem. Nitrates are not the only pollutants attributable to irrigation, so are plant nutrients in general, pesticides, and heavy metals. Pharmaceutical compounds emerge as pollutants when wastewater is used for irrigation without any previous treatment (Siemens et al., 2008). Applying saline water continuously for irrigation through surface drip irrigation (DI) systems might result in salt accumulation close to the soil surface (DeMalach and Pasternak, 1993; Oron et al., 1995). Under conventional on-surface DI, during irrigation or precipitation, the accumulated salts close to the soil surface can migrate downwards and reach the main root zone.

This process may inhibit water and nutrient uptake, consequently affecting the crop growth and yield (Hanson, 1995). In order to offset the osmotic shock imposed on the crop by the leached salts, a practical solution was proposed. It was suggested to further leach the accumulated salts in the main root zone to deeper layers by continuing to drip irrigate simultaneously with the periods of precipitation. Alternatively, Oron et al., (1990) and Phene et al., (1990) have proposed that this problem can be overcome by applying saline water through a subsurface drip-irrigation (SDI) system. It is anticipated that under SDI, the salt front is partially driven down into the deeper soil bulk media and to the periphery of the root zone, thus minimizing the risk of damaging the main roots of the plants. Moreover, the improved moisture conditions near the emitter offsets and the inhibiting effects of the presence of the salts in the saline water (Hanson, 1995). Additionally, Phene et al., (1987) reported that since the SDI is installed below the soil surface, a properly managed system could increase the advantages of conventional DI systems, especially in the areas of efficient water and nutrient utilization, salinity management and deep percolation.

\subsection{Subsurface drip irrigation method for improve crop quality and productivity}

Subsurface irrigation is one of micro irrigation methods in which water is applied below the soil surface through buried emitter including drip tapes, perforated pipe, clay pipe and tube. This method can ensure timely allocation of a suitable amount of water and nutrients to the root zone and crop water requirement, which may improve crop quality and productivity (Sun et al., 2016). The relatively dry soil on the surface during subsurface application can also prevent the growth of weeds (Sagi, 2006; Kreij et al., 2003). Increasing in the working life of the system as vandalism, and solar radiation degradation are avoided; ploughing and other cropping practices are facilitated, and the development of fungal disease are diminished (Martines and Reca, 2014). In addition, subsurface irrigation has a special advantage of securing system safety against pilferage and damage by animals and during intercultural operations. The value of subsurface irrigation promoted during the initial period of 1980s, rapidly promoted during the second half of 1980s and continuing its development at present mostly in areas having insufficient water and environmental problems linked to irrigation and where the wastewater is used for irrigation.

Nowadays, the most common subsurface irrigation has been used widely is subsurface drip irrigation (SDI). Camp (1998) reviewed the results of some previous works that compared the crop yield both the results of some previous works that compared the crop yield both in subsurface and other different methods of irrigation. He concluded that crop yields for subsurface drip systems were equal or better than the other systems in all cases, including different crops, soils, and cultivation condition. A few comparative studies (Fandino et al., 2012; Cancela et al., 2015) showed slightly higher grapevine water uptake and coefficient under subsurface drip irrigation than under surface drip. While 
Miguel and Fransisco (2007) found that tomato, yields increased by $66.5 \%$ when using subsurface drip irrigation as compared with the surface drip irrigation. Despite of its numerous advantages of subsurface drip irrigation, the SDI also has many issues to be solved as the associated equipment development and technical research is not mature. Many studies have regarded the hydraulic characteristics of embedded emitters and factors affecting the flow rate of embedded emitters. For example, Xu et al., (2003; 2004) explored the effects of emitter type, operating pressure on the flow rate using the orthogonal experimental design. Lazarovicth et al., (2006) stated that in contrast to surface drip irrigation, soil hydraulic properties might affect SDI dripper discharge rates. During irrigation, positive water pressure backpressure may develop in the soil near a subsurface dripper following the principles of flow from a point source (Philip, 1992). The magnitude of pressure developed depends on soil texture, dripper discharge, potential cavity development near the dripper, and drip system hydraulic properties (Shani et al., 1996). Develop positive soil water pressures, resulting in a decreased discharge from subsurface drippers; this effect is most pronounced with non-pressure-compensated drippers operating at low pressures (Shani et al., 1996).

In addition, variations in soil hydraulic properties within a field, and different cavity formation during installation, cause a discrepancy in pressure buildup adjacent to individual drippers and subsequent non-uniform discharge and water application (Warrick and Shani 1996; Xu et al., (2004) Therefore, selected drippers discharge should be sufficiently low to closely match with root uptake rate of water (Lazarovitch, 2006). Most SDI systems are designed to operate at pressure heads greater than $7 \mathrm{~m}$. In general, pumps are needed to develop such pressures. There is increasing interest in SDI systems designed to operate at much lower pressures, e.g., 1.5-2.0 m e.g., (Su et al., 2000). Such systems may eliminate the need for pumps, allow an increase in an irrigated area without increasing pump capacity, or reduce the discharge rate without a decrease in orifice size. Low-pressure systems generally cost less than systems designed to operate at high pressure, which may encourage their adoption. Such SDI systems are also a possible solution toward low discharge continuous irrigation, which would maintain a high root zone, soil water content and hydraulic conductivity, thus maintaining high water availability to plants (Rawlins and Raats 1975; Radin et al., 1989).

Low-pressure SDI systems may be especially advantageous in developing countries, where access to electricity can be problematic. However, systems designed to operate at low pressures are particularly prone to the soil-induced changes in dripper discharge. The performance of subsurface irrigation should be quantified for its proper design, management, operation, and provide irrigation water use efficiently. Quantification allows the users to determine and control the drippers or emitter discharge and operating pressure of system, backpressure effect on dripper discharge, formation of cavity and application of irrigation water to meet the crop water requirements. Determining the appropriate depth placement of the emitter requires consideration of soil properties and the root distribution of crop (Patel and Rajput, 2008). Information on root distribution is useful to understand crop responses to irrigation and fertigation, especially with the limited wetted soil volume that develops under subsurface drip (Phene et al., 1991). Phene et al. (1990) showed that root length and rooted soil volume of sweet corn could be improved by frequent irrigation with shallow subsurface drip irrigation. They revealed that frequent irrigation maintained a portion of the root zone within the optimal matric potential range. In high frequent irrigated corn, root length density and water uptake patterns are determined primarily by the soil water distribution under drippers, whether the drippers are placed on, or beneath the crop row (Coelho and Or, 1999). Most of the root system is concentrated in the top $40 \mathrm{~cm}$ of the soil profile in drip irrigated processing tomatoes (Xu et al., 2003, 2004). Supply of aerated water with subsurface drip irrigation can maintain aeration of the root zone in heavy clay soils significantly increase yield of vegetables soya bean and zucchini (Bhattarai et al., 2004). In Subsurface drip irrigation, the choice of drip tape depth is influenced by crop, soil, climate characteristics and anticipated cultural practices, but generally ranges from 0.02 to $0.7 \mathrm{~m}$ (Camp, 1998). It is often in the range of 0.05 to $0.2 \mathrm{~m}$ for shallow rooted horticulture crops. From the literature, a depth of $0.15 \mathrm{~m}$ for lettuce would be appropriate on sandy soil.

Although installation depth is generally decided for horticulture reasons, another consideration for determining depth is that deeper placement of $0.45 \mathrm{~m}$ may be required if the primary aim is to reduce soil evaporation and capture the potential benefit of improving water use efficiency (both in yield and quality) (Bryla et al., 2003 and Batra et al., 2000) studied on SDI under different system design, installation, application and operation. They suggested that lateral SDI should be installed at a shallower 
depth on coarse-textured soil and slightly deeper for finer-textured soil for multi years or long-term use of SDI system. Irrigation scheduling is one of the important components to achieve higher irrigation efficiency under any subsurface irrigation system. Irrigation scheduling is influenced by many factors such as soil, crop, climate, water supply and cultivation practices. Thus, it is essential to develop an efficient irrigation scheduling under prevailing local conditions. Various methods based on the estimated crop evapotranspiration rate, ratio of irrigation water to cumulative pan evaporation (Batra et al., 2000) and soil water depletion are widely used for scheduling irrigation in many cultivation crop practices. Irrigation application with $100 \%$ of crop evapotranspiration provided the highest yield in subsurface drip system when the drip tape was placed at a depth of $10 \mathrm{~cm}$ (Patel and Rajput, 2008; PSDA, 2008; Imanudin and Prayitno, 2015; Purwartini and Suhaeti, 2017; Palada et al., 2011).

\subsection{Irrigation water productivity and water use efficiency}

On-farm strategies, water productivity can be used as indicator to evaluate the performance of irrigation system. There are several definitions exist for the term of water productivity. It may convey as the physical ratio between yields and (productive or unproductive) water use (Zwart and Bastiaanssen, 2004) or between the value of the product and water use (Vazifendousta et al., 2008; Siedel et al., 2015).

The water productivity (WP) term describes the ratio between the quantity of an (agricultural) product (biomass, yield) and the amount of water depleted or diverted. Until 2050, human population is projected to increase to 9 billion people and it is estimated that 70 per cent of additional food will have to be produced in order to over the next 40 years. Meeting this challenge, the "Water Productivity term" plays a crucial role in modern agriculture that aims to increase yield production per hectare per unit of water used. Bearing in mind the consequences of climate change, an increase in water productivity helps to cope with predicted and serves as an indicator for (FAO 2015). Expert survey participants in the World Water Scenarios Project of the United Nations World Water Assessment Programme (WWAP) ranked increases in water productivity in agriculture as the most important development affecting water (FAO 2012). The concept of water productivity in agricultural production systems focuses on "producing more food with the same water resources" or "producing the same 'amount of food with less water resources". Water productivity measures how a system converts water into goods and services, it is a measure of the beneficial output in relation to the water actually consumed, the ratio of the net benefits from crop, forestry, fishery, livestock and other mixed agricultural systems to the amount of water used in its production process. In a simple way, water productivity is defined as "crop production" per unit "amount of water used". The basic equation to calculate WP is: WP = Output derived from water use/ water input. The water input can be expressed by a set of choices according to the aim of the investigation. For example:

- Irrigation diversion

- Gross/net inflow

- Evapotranspiration

- Precipitation

The water output or the benefits can also be measured with various terms, for example with

- Economic value (monetary)

- Physical mass (kilogram)

- Nutritional value (calories)

Water use efficiency (WUE) is defined as the ratio of the total dry matter of harvested (economic) portions of the crop produced per unit water consumed. Significant improvements in yield have been documented with micro irrigation without significant increases in the consumed water leading to improved water use efficiency (FAO 2015). Intercropping or even multiple cropping of vegetables and melon crops with subsurface micro irrigation increased yields, improved water use efficiency, and reduced water applications between cropping seasons (FAO 2012).

Continuous cropping is a practical way to increase water use efficiency where water prices are increasing and urbanization occurred (Lamm et al., 2007). The irrigation water use efficiency can be defined as the yield of plant product per unit of irrigation water used during cultivation and it is a measure of the productivity of the irrigation water (Martinez and Reca, 2014). The efficiency of drip irrigation water is highly dependent on evaporation losses occurring from the constantly saturated soil 
beneath emitters. The Advent of subsurface drip irrigation is in part an approach to curb this inefficiency. Various methods of evaporation reduction, such as mulching that have been employed in irrigation

\subsection{Subsurface water flow}

Subsurface irrigation systems are becoming increasingly popular to supply irrigation water, nutrients, and pesticides directly to the root zone efficiently. Increasing the efficiency of irrigation water use is a major concern for coping water scarcity in arid and semiarid regions. Subsurface irrigation with a ring-shaped emitter is one of subsurface irrigation methods that has been recently developed and introduced in some arid regions of Indonesia to cultivate annual and perennial crops (Saefuddin et al., 2014; Sumarsono et al., 2018). A ring-shaped emitter made from a standard water hose is economically affordable for small-scale farmers in such rural areas Fig. (2).

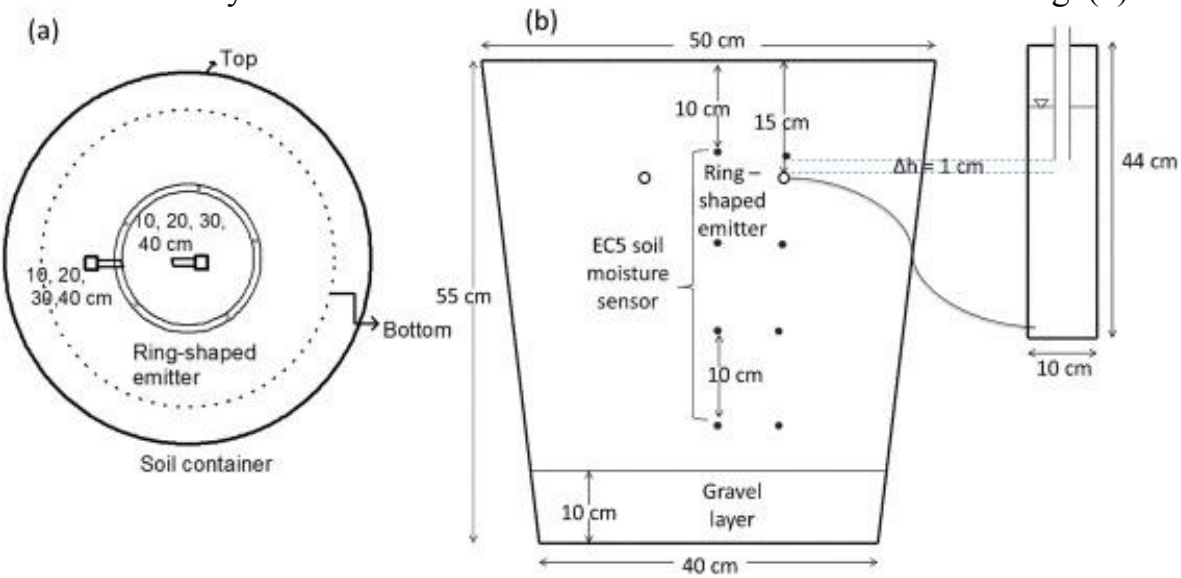

Fig. 2: Top view (a) and cross-section (b) of the soil container used in the laboratory experiments with a ring-shaped emitter. After Sumarsono et al. (2018)

A low-cost subsurface irrigation system can generate benefits for small-scale farmers who have scarce water resources. A ring-shaped emitter made from a standard rubber hose has been developed and introduced for subsurface irrigation in Indonesia. It is a low-cost irrigation technology based on indigenous materials and skills. To build a ring-shaped emitter of the original design, a rubber hose is bent into a ring shape with a diameter of about $20 \mathrm{~cm}$, and then five $5-\mathrm{mm}$ holes are drilled into it at even intervals. Next, the entire ring-shaped hose is covered with a permeable textile so that water can infiltrate in all directions around the buried emitter. Water is applied from a water tank connected to the emitter by adjusting the pressure head imposed at the inlet of the emitter. Although it has been successfully used in practice, the performance of the ring-shaped emitter has not been evaluated in detail. Additionally, because the ring-shaped hose is fully covered with the textile, it may be difficult to detect any malfunctions or repair it. To promote the ring-shaped emitter for subsurface irrigation among small-scale farmers in arid or semi-arid regions, it is important to design an emitter that is easy to maintain. This study proposes a reduction in the number of holes and a change of covering method. Because the number of experiments that can be carried out to evaluate the performance of alternative ring-shaped emitters is usually limited, numerical simulations can be performed in addition to experiments. The main objectives of this study thus were 1) to experimentally investigate the water movement around a buried ring-shaped emitter and 2) to numerically evaluate the effect of modifying the design of the ring-shaped emitter on soil water dynamics around the emitter. Numerical simulations were carried out using HYDRUS, one of the most complete packages for simulating variably saturated water flow in two- or three-dimensional domains. HYDRUS simulations in a three-dimensional domain were performed using the soil hydraulic parameters that were optimized against experimental data collected during experiments with the original ring-shaped emitter. Simulation results confirmed that reducing the number of holes does not significantly affect the water availability in silt for model plants, such as tomato and strawberry, and that covering the entire emitter is not necessary. Partially covering the emitter allows one to maintain the emitter much more easily compared to the original fully covered emitter. 
To make the original design ring-shaped emitter, a water hose is first bent into a ring-shaped with a diameter of about $20 \mathrm{~cm}$. Five $-5 \mathrm{~mm}$ holes are drilled into it at an even interval. The entire ring-shaped hose is then covered with a permeable textile so that water can infiltrate through permeable textile in all directions. Water is supplied from a water tank through a tube to the inlet of the emitter. Although, subsurface irrigation with the ring-shaped emitter was successfully practiced cultivating crops in Indonesia, the design and the operation of the entire system have been purely empirical. The dimensions spatial extent (or the volume) of wetted areas around emitter is crucial to obtain an optimum design of the emitter. The precise distribution of soil water content around a ring-shaped emitter must be known in order to properly manage subsurface irrigation with ring shaped emitter to wet the plant root zone uniformly, which will increase water use efficiency of water or fertilizer use, and to prevent water losses due to either evaporation in soil surface or deep percolation to groundwater. Moreover, hydraulic properties of soil are critical factors to determine the infiltration phase. Therefore, by applying high pressure head of water applications in subsurface irrigation with ring-shaped emitter requires knowledge of regulating the irrigation discharge rates that involve the quantity of water passing through the root zone based on soil hydraulic properties.

Kandelous and Šimůnek (2010) compared three theoretical modeling approaches (numerical, analytical, and empirical) for calculating wetting patterns under the surface and subsurface irrigation drip irrigation that are important for optimal design. They concluded that numerical model using HYDRUS-2D (Šimůnek et al., 1999; 2008) provided good predictions of soil water content distribution compared to other models. Recently HYDRUS numerical model (Šimůnek et al., 1999, 2006, 2008, and 2016) has been widely used to simulate water movement under different irrigation designs and management scenarios. For example, Fares et al., (2001) examined HYDRUS-2D to evaluate the performance of drip irrigation in three different soil types. The results highlighted the water movement more vertically in sandy soils, while the horizontal distance wetted volume was higher in clay soil. Performance of a drip system is better in clay soils than sandy soils.

Whereas, Cote et al., (2003) investigated the wetting patterns under subsurface drip irrigation (SDI) without considering water uptake by plant roots. They used three different soil types including sand, silt and silt clay loam with four different irrigation fluxes. They found that subsurface drip irrigation can improve plant water availability in medium and low permeability fine-textured soil, providing that design and management were adapted to account for their soil hydraulic properties. In addition, in highly permeable soil coarse-textured soils, water and nutrients are moved quickly downwards from the emitter. Gärdenäs et al. (2005) studied the effect of soil hydraulic properties under subsurface irrigation considering root water uptake. They concluded that percolation was highest for coarse textured soils (sandy loam soil) and lowest for finer-textured soil (silt clay soil).

Provenzano (2007) assessed the accuracy of HYDRUS-2D by comparing simulation results and experimental observations of matric potential for subsurface drip irrigation system in a sandy loam soil with a 10- cm installation depth, and found satisfactory agreement. Siyal et al., (2009) used HYDRUS$2 \mathrm{D}$ to investigate the performance of pitcher irrigation system and found the close agreement between observed and simulated soil water content during subsurface water application through pitcher.

While Nagazawa et al. (2008) examined HYDRUS-1D to investigate the performance of the buried porous bottle for subsurface irrigation by applying different water pressure head applications in quartz sand soil. They found the predicted of soil water contents generally fitted well with the observed data. In addition, the rate of deep percolation and evaporation from the soil surface can be reduced by applying the pressure head smaller than the air entry value of the soil.

Overall, they concluded that HYDRUS 1D, and 2D/3D is an effective tool for investigating and designing irrigation management practices. In order to provide of design and management for subsurface irrigation with ring-shaped emitter, the first step that should be taken into account is to investigate the wetting patterns and soil water content distributions around buried ring-shaped emitter by considering the soil hydraulic properties and the amount of water irrigation applications. Therefore, the aims of this work are to (a) study the influence of soil hydraulic properties on soil water movement around buried ring-shaped emitter, (b) calibrate and validate the capacity of the HYDRUS 2D/3D numerical model in assessing the water flow in soil under subsurface irrigation with original design ring-shaped emitter. To address these objectives, the laboratory experiments were first carried out to monitor changes in the soil moisture content at given positions during water applied with the buried original ring-shaped emitter. While the emitter was developed to aid plant cultivation, the laboratory 
experiments were carried out without any plants in this work to avoid any difficulties associated with plant root water uptake. Two different water pressure head applications; 1 and $5 \mathrm{cmH}_{2} \mathrm{O}$ are applied for two soil types, sand and silt. Therefore, there are four simulations were considered to express the infiltration processes. HYDRUS was then calibrated with the experimental soil water content data collected during the subsurface water application experiments with the original ring-shaped emitter. The calibrated model was next used to predict other experimental data for validation.

\subsection{Yield and water productivity of bell pepper (Capsicum annum L.)}

Efficient irrigation water use is important in arid and semi-arid regions where water supply is limited in supporting agriculture production. Soil water dynamics in the root zone under various environmental and crop systems are very complex and its understanding is critical for optimizing irrigation management. Thus, it is necessary to investigate soil water dynamics around buried ringshaped emitters under such condition by considering several factors including crop management system as well as root distribution and crop water requirement in agro-climate conditions to enhance promoting ring-shaped emitters for subsurface irrigation to obtain higher water use efficiency. A proper emitter design and effective water management are crucial in developing water saving agriculture. In the previous chapter, an alternative ring-shaped emitter design (Saefuddin et al., 2018) was proposed by reducing the number of holes and changing the covering method. For modified ring-shaped emitter designs, the number of holes was reduced from five holes, which was originally used, to 2 holes to improve water use efficiency and was partially covered only around the holes for easier maintenance and repairing. The performance of the original and alternative ring shaped emitter designs was evaluated numerically using HYDRUS 2D/3D software package (Šimůnek et al., 2016) under various soil types. In the numerical analysis, the effect of different emitter configurations on the evaluation of wet volumes around the emitter was assessed using soil water stress to the plant roots. Therefore, root water uptake was computed as an indirect indicator of how well the ring-shaped emitter distributed water around the emitter uniformly to the root zone.

As a result, regardless of the soil type, the number of holes can be reduced from original five holes to 3 or 2 holes. The emitter with new hole configuration resulted in higher water use efficiency and provided a proper condition for plant roots to uptake water in the root zone. The emitter was partially covered with a permeable textile to simplify the repairing and maintenance. Yield production is dependent on the amount of irrigation water and irrigation frequency. Bell pepper (Capsicum annum L.) is one of the most susceptible crops to water stress in horticulture (Ferarra et al., 2011). Costa and Gianquinto (2002) reported that continuous water stress significantly reduced the total fresh weight of fruit, while Antony and Singandhupe (2004) concluded that the total pepper yield was poor at lower amounts of irrigation.

Inappropriate irrigation schedule and management could result in water stress for the plant. Therefore, the precision irrigation is crucial to meet crop water requirement. In addition, soil water storage and soil water distribution in the root zone are one of the main factors to optimize irrigation. A better understanding of root density and distribution pattern and root water uptake under subsurface irrigation will allow for a more accurate simulation of soil water distribution for plants. Numerical simulation of water flow and plant root water uptake can help in understanding dynamic process of soil water during irrigation. Because of the reliability and flexibility of HYDRUS 2D/3D to accommodate different types of boundary conditions and root water and nutrient uptakes, and because of its ease to use due to a graphical user friendly interface, the model has been widely and successfully used to investigate and evaluate the designing subsurface irrigation management practices involving a wide range of crops (Ityel et al., 2011; Bufon et al., 2012; Kandelous et al., 2012; Lila et al., 2013; El-Nesr et al., 2014; and Ghazouani et al., 2015). In previous chapters, HYDRUS has been used with a full three-dimensional flow domain to evaluate the effect of modifying the ring-shaped emitter design for subsurface irrigation without considering plant cultivation, e.g., crop growth, (Saefuddin et al., 2018).

Therefore, experimental validation of the HYDRUS model by considering crop cultivation is needed to explore if subsurface irrigation with the ring-shaped emitter is suited for the real field conditions. With these backgrounds in considerations, comprehensive experimental and simulation investigations were carried out under glass-house bell pepper cultivation. The main objectives of this chapter were 1) to investigate experimentally and numerically water dynamic around the buried ring- 
shaped emitter during bell pepper cultivation, and 2) to evaluate the performance of the ring shaped emitter in terms of water productivity and irrigation water productivity. Initially, the simulated soil water contents and the measured soil water content in the cultivation experiments were compared to validate the performance of the HYDRUS three-dimensional model in simulating soil water movement around buried ring shaped-emitter. Then, parameters of the root water uptake model were computed to evaluate how well the ring-shaped emitter provided appropriate soil water in the root zone. Since a new version of the HYDRUS software package (Šimůnek et al., 2018) has been released recently that allows simulating plant root growth to characterize the actual of root water uptake, the observed plant growth data can be modeled for analysis that is more comprehensive. The results of the simulations were finally compared in terms of the ratio between actual transpiration and the total amount of irrigation water, during the entire growing season, in other words in terms of water use efficiency.

\subsection{Crop water consumption}

Crops need water for transpiration. The plant roots uptake or extract water from the soil to live and grow. The main part of this water does not remain on the plant but escapes to the atmosphere as vapor through leaves and stems. This process is called transpiration. Transpiration happens mainly during the daytime where, water from an open water surface escapes as vapor to the atmosphere during the day. The same happens to water on the soil surface and to water on the leaves and stem of a plant. This process is called evaporation. The water need of a crop thus, consists of transpiration plus evaporation. Therefore, the crop water need is referred to as "evapotranspiration". The potential evapotranspiration is defined as the value of evapotranspiration when soil is sufficiently wet, which is affected by atmospheric conditions such as net radiation, wind speed, air temperature and relative humidity. The value of the evapotranspiration usually ranges from 3 to $6 \mathrm{~mm}$ per day for summer crops in temperatemonsoon areas (Miyazaki et al., 1993).

Crop growth stages, environmental conditions and crop management influence crop evapotranspiration (ETc). The crop water requirement (CWR) is the sum of ETc for the entire crop growth period. When management or environmental conditions deviate from the optimal condition, the rate of evapotranspiration has to be adjusted to the prevailing conditions and is called adjusted or actual crop evapotranspiration $(E T c)$. Both $C W R$ and ETc concepts apply to either irrigated or rainfed crops. For irrigated crops, the concept of $C W R$ has to be complemented by that of an irrigation water requirement $(I W R)$, which is the net depth of water $[\mathrm{mm}]$ required by a crop to fully satisfy its specific crop water requirement. The IWR is the fraction of $C W R$ not satisfied by rainfall, soil water storage and groundwater contribution. When it is necessary to add a leaching fraction to assure appropriate leaching of salts in the soil profile, this depth of water is also included in IWR. In practice, IWR has to be converted into gross irrigation requirements to take into consideration the efficiency of the irrigation systems utilized. In crop management practices, crop water requirement can be used as a guide to determine the balance between the amount of extractable soil water available for the crop and the amount of water needed to be supplied at a particular growth stage. In a wet soil, as water has a high potential energy, it is relatively free to move and is easily taken up by plant roots. In a dry soil, however, as capillary and absorptive forces to the soil matrix bind water, crop plants less easily extract it. When the potential energy of the soil water decreases to a threshold value (usually, the lower limit of plant extractable soil water), the crop is unable to extract the water from the soil and becomes water stressed. Doorenbos et al. (1992) defined crop water requirements are the depth of water needed to meet the water loss through evapotranspiration $(E T c)$ of a disease-free crop. To calculate ETcrop a three-stage procedure is recommended by Doorenboos et al. (1992).

1. The effect of climate on crop water requirements is given by the reference crop evapotranspiration $(E T o)$. ETo is expressed in $\mathrm{mm}$ per day and represents the mean value over the period based on the type of climatic data available. The most common method to calculate the reference evapotranspiration is based on the Penman-Monteith equation (Allen et al., 1998).

2. The effect of the crop characteristics on crop water requirements is given by the crop coefficient $(K c)$ which presents the relationship between reference (ETo) and crop evapotranspiration $(E T)$ or ETcrop $=K c$. ETo. Values of Kc vary with the crop, its stage of growth, growing season and the prevailing weather conditions. The unit of ETc is in $\mathrm{mm}$ day-1. 
3. The effect of local conditions and agricultural practices on crop water requirements includes the local effect of variations in climate over time, altitude, size of fields, advection, soil water availability, salinity, and method of irrigation and cultivation methods and practices.

\subsection{Their effects on root distribution}

Different irrigation systems influence root development by changing the availability of water at different depths in the soil profile. A healthy root system is essential for all crops because it facilitates the uptake of water and nutrients. Considering of the root zone at various stages of crop growth is important to determine the amount of irrigation depth and frequency photo. (2).

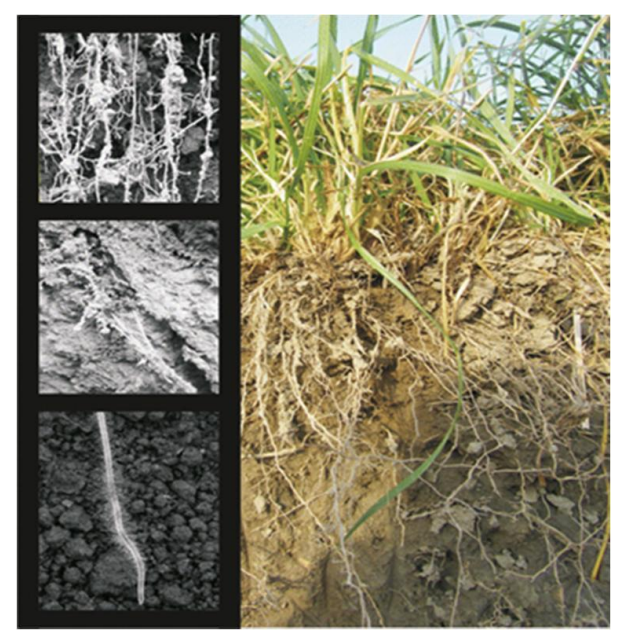

Photo 2: Root zone as dynamic interface between plant and soil plays a key role in crop water supply. Many processes are still poorly understood, and therefore, development of new agronomic measures for root zone management is a strategic challenge to mitigate water stress in cropping systems

Shallow rooted crops can only extract water from a limited depth and may require short and frequent irrigations. Deep rooted plants, on the other hand, are able to extract water from deep down, but can be prone to root disease if the subsoil becomes saturated (Hillel, 1980). One possible reason for the difference observed between the responses of pot-grown and of field-grown plants to the soil-water regime is the difference in root distribution with depth. In a pot, root density can be uniform, while in the field, it generally varies with depth. Furthermore, the roots present in different layers maybe exhibit different water uptake and transmission properties. For instance, the roots in the deeper layers may offer greater resistance to water movement within the plant than the roots of the upper layer (Hillel, 1980). Rooting depth can be determined by digging out the whole plant, shaking the soil off or digging a soil pit and then measuring the depth of the root system. Rooting depth and depletion fraction (p), which is the fraction of total available water that can be depleted from the root zone before moisture stress occurs, are vital factors in determining how much water should be applied. The distribution of RWU in the soil profile is greatly affected by the spatial-temporal root distribution.

More specifically, RWU is generally assumed a direct function of root length densities (RLDs) (Feddes et al., 2001). In order to represent the interactions between root development and soil water status, the dynamics of root distributions need to be properly accounted for (Krounbi and Lazarovitch, 2011). Direct measurements of RLD distributions and their temporal dynamics are important additional information that can be used to constrain other parameters related to stress and water uptake compensation functions in RWU models (Cai et al., 2017). Either the length per unit volume of soil $\left[\mathrm{cm} \mathrm{cm}^{-3}\right]$ or the length per unit surface of soil $\left[\mathrm{cm} \mathrm{cm}^{-2}\right]$ defines Root length density. The former is used to determine the root length distribution with depth, and the latter is used to determine the amount of roots per unit ground surface or crack surface. Root development influenced by the water supply (Miyazaki et al., 1993). Soil water uptake under different soil moisture regimes is a function of root growth, where under unfavorable soil water conditions plants improve their ability to increase water uptake by extensive root growth and proliferation in the soil matrix. In this regard, spatial and temporal 
variations of soil water content, soil texture, and soil structure have major impacts on root growth and distribution in soil matrix (Dexter, 2004).

Root growth is an important stage of plant growth. Many studies have investigated many aspects of plant roots, such as their growth and distribution, water absorption, and adaptive self-regulation (Miyazaki et al., 1993; Ehlers et al., 1991).

Plant roots can extract water from various sources, including soil water, irrigation water, rainwater and groundwater (Shi et al., 2003; Sun et al., 2005). The implementation of water-saving irrigation measures in orchards influences the distribution of roots, maximum root depth, and water absorption by roots (Bertrand et al., 2014; Zencich et al., 2002). In addition, the distribution range of roots shifts in accordance with the soil water content (Ehlers et al., 1991).

The stable oxygen isotope composition varies significantly amongst irrigation water, soil water at different depths, and groundwater because of the physical processes of evaporation, penetration, and slow chemical reactions (Allison et al., 1982; Dawson et al., 1996). Specifically, water absorbed by plant roots is considered to contain a mixture of all possible sources of water. Therefore, the relative contribution rate of each source of water to plant growth can be quantitatively determined by comparing the relationship between the water content of xylem and the isotopic characteristics of other sources of water (Flanagan et al., 1991). This method forms the theoretical basis for the evaluation of plant water use with the stable oxygen isotope method. Relative to traditional methods, such as root excavation and soil moisture measurement, the stable isotope technique is perceived as a more valuable tool for more accurate assessment of water uptake patterns during crop growth (Du et al., 2011; Thorburn et al., 1995). This method causes minimal harm to the root environment and is thus suitable for long-term research (Wang et al., 2010). Yano et al. stated that the stable hydrogen isotope composition of dryfarmed rice fields in the lowlands fluctuates due to the influence of precipitation (Yano et al., 2006). Trees adapt their water absorption in the growing season and under varied soil moisture conditions Yang et al., (2009). Cao et al., 2018), found that cherry trees could absorb soil water and irrigation water at different depths depending on the degree of water deficit during different growth stages These findings indicate that the variation in and the ability to adapt the water extraction strategy can benefit root growth and improve a plant's water-use efficiency, which is critical for irrigation water productivity and final yields in water limiting environments. Several methods can be adopted to quantitatively assess the spatial distribution of roots in soil, including profiling, soil drilling, clod method, or excavation of intact root structures (Bohm et al., 1996). Despite the various advantages of the stable isotope methods, obtaining a thorough understanding of root growth and root distribution is considered the most direct means, and the most challenging, for understanding crop growth, especially for large perennials such as fruit trees (Black et al., 2010).

By far, the profiling method is the most commonly used method in orchard research (Oskamp et al. 1932; Kolesnikov 1971). Many factors, including soil properties, soil types, rootstock types, and orchard management Atkinson and Wilson (1980), Atkinson (1983) influence Crop root distribution). Different research groups have reported an important link between the root distribution of fruit trees and the soil moisture characteristics Gil et al., (2008), Black et al. (2010). Based on the root excavation method, Williamson et al. and Parker and Meyer evaluated the root distribution of peach trees (Black et al. 2010; Parker et al. 1996). Yao et al. examined the growth, variation, and distribution of apple tree roots under different orchard ground management regulations (Yao et al., 2009). Liang et al. studied the spatial distribution characteristics of the root system of intercropped apricots (Paltineanu et al., 2015). Paltineanu et al. studied the root distribution of apricot and peach trees Paltineanu et al., (2015), Paltineanu et al., (2016) , Ceausescu et al., (1982), analyzed the relationship between root morphology, and stomata, solar radiation angle, orchard management and fertilization . Cherry tree (Prunus avium) is an important fruit tree species in the suburbs of Beijing, China. Hence, it is essential to study the effects of irrigation in agricultural water-saving practices on cherry root distribution, root water absorption characteristics and water-use efficiency. Most of the existing studies focused on forest, grassland, and field crops to clarify the effects of different sources of water on root distribution and water absorption (Parker et al., 1996; Bertrand et al., 2014; Black et al., 2010; Gil et al., 2008).

However, few studies focused on fruit trees to assess how different water sources, especially different irrigation methods, affect root water uptake patterns and then influence the root redistribution Fig.(3a\&b). The selection of water source and estimation of the possible contribution of each water 
source via irrigation water to total water absorption under different irrigation methods requires an indepth study of root water uptake and root system distribution in cherry orchards (Wu et al., 2016).
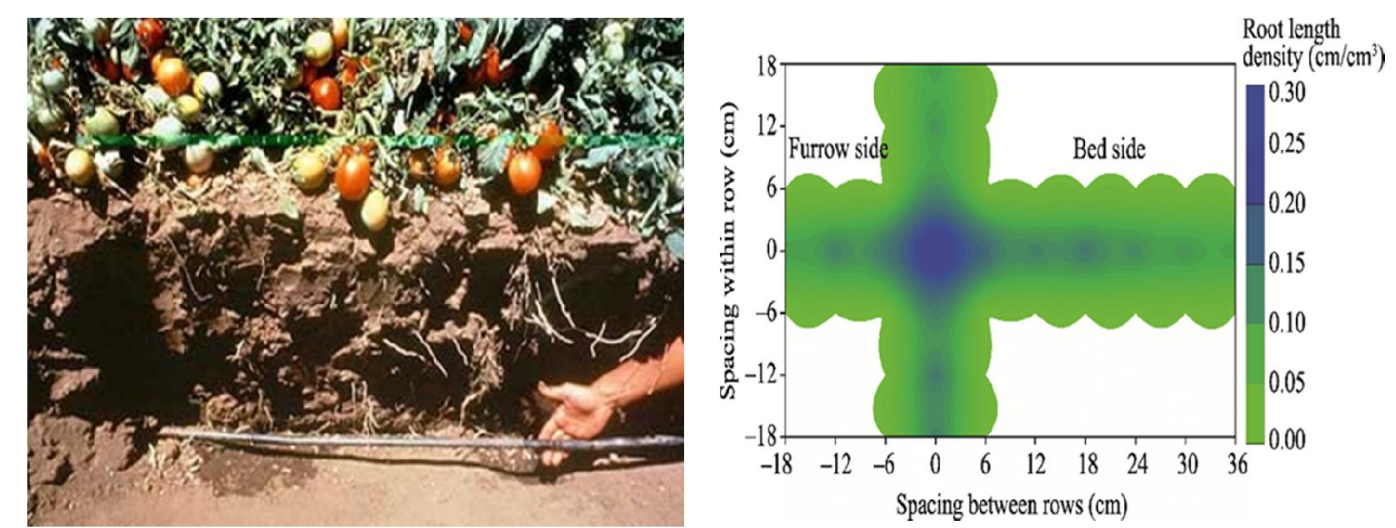

Fig. 3a: Horizontal distribution of root length density of tomato plants under two different irrigation system in two-dimensional root length density used in the root water uptake function

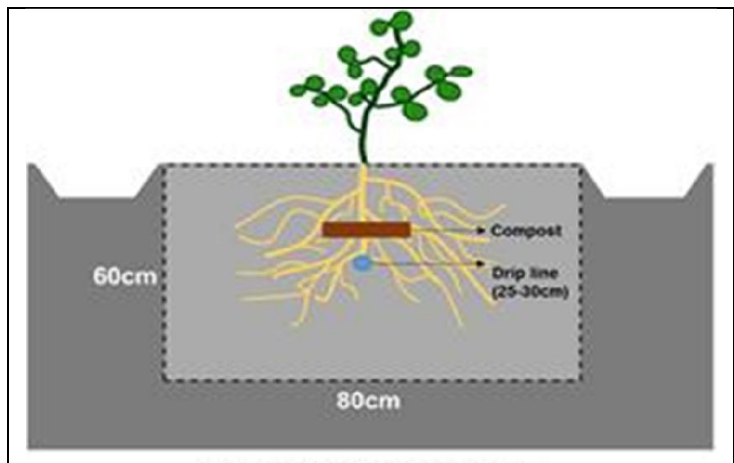

Subsurface drip irrigation

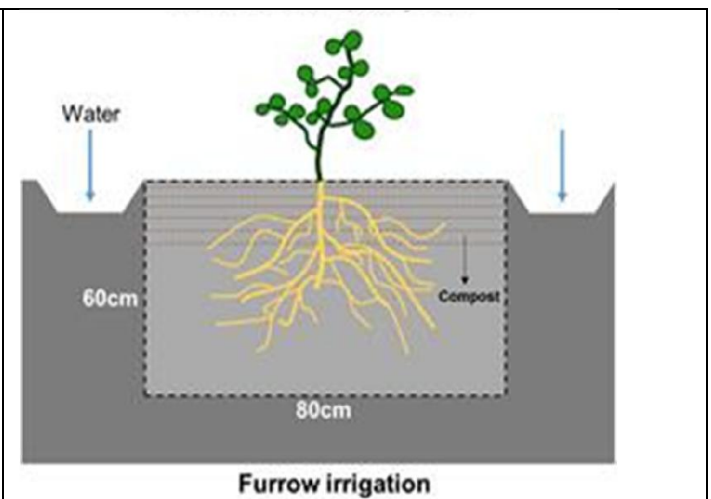

Furrow irrigation

Fig. 3b: Diagram of irrigation method, fertilizer application, and soil profile surface in subsurface drip and furrow irrigation systems.

Meng et al. (2020) they stated that root exploitation of soil heterogeneity and microbially mediated rhizosphere nutrient transformations play a critical role in plant resource uptake. However, these processes change under water-saving irrigation technologies remains unclear, especially for organic systems where crops rely on soil ecological processes for plant nutrition and productivity. A field experiment were conducted to study the effectiveness of water saving (SDI) and organic fertilizer application altered root traits and rhizosphere processes as compared to traditional furrow irrigation (FI) in an organic tomato system, on root exploitation. Root distribution and morphology, the activities of $\mathrm{C}, \mathrm{N}$, and P-cycling enzymes in the rhizosphere, the abundance of rhizosphere microbial N-cycling genes, and root mycorrhizal colonization rate under two irrigation strategies were determined. Tomato plants produced shorter and finer root systems Fig. ( $3 a \& b)$, with higher densities of roots around the drip line, lower activities of soil C-degrading enzymes, and shifts in the abundance of microbial Ncycling genes and mycorrhizal colonization rates in the rhizosphere of (SDI) plants compared to furrow irrigation ( FI).

Meng et al. (2020) reported that subsurface drip irrigation (SDI), led to $66.4 \%$ higher irrigation water productivity than FI, but it also led to excessive vegetative growth and $28.3 \%$ lower tomato yield than FI. They also suggesting that, roots and root-microbe interactions have a high potential for coordinated adaptation to water and nutrient spatial patterns to facilitate resource uptake under SDI. However, mismatches between plant needs and resource availability remain, highlighting the importance of assessing temporal dynamics of root-soil-microbe interactions to maximize their resource-mining potential for innovative irrigation systems. 
Plants can regulate root system development to maximize acquisition of soil moisture and nutrient resources whose distribution is gradually affected by irrigation system (Meng et al., 2020). This plasticity can be achieved through different strategies including spatially targeted root proliferation to mine nutrient- and moisture-rich patches while avoiding resource poor areas (Wu et al., (2016). Plasticity occurs over time as well: plants can develop rapid root regrowth along with increased root physiological activity, such as $\mathrm{N}$ uptake and hydraulic conductivity, following the soil rewetting caused by rainfall or irrigation events (Atkinson and Wilson 1980; Atkinson1983; Black et al. 2010). A better understanding of root responses to wetting patterns caused by different irrigation strategies will contribute to the design of new resource-saving irrigation technologies and the development of effective root for irrigated landscapes (Atkinson and Wilson 1980; Atkinson1983). Integrating rhizosphere processes mediated by root-associated microbes with root developmental patterns is also necessary to enhance our mechanistic understanding of plant adaptation to resource availability under different irrigation strategies (Meng et al., 2020). Soil microorganisms participate in vital biogeochemical processes that influence plant nutrient uptake and nutrient retention (Black et al., 2010). For instance, nutrient-limited bacteria and fungi release extracellular enzymes that regulate the depolymerization of soil organic matter $(\mathrm{SOM})$ and thus mediate the overall carbon $(\mathrm{C})$ and nitrogen $(\mathrm{N})$ cycling rate in soils (Atkinson and Wilson, 1980; Bohm et al., 1996).

In addition, soil microorganisms compete with roots for mineralized soil nutrients such as inorganic N (Jarvis, 1989) Quantifying microbial genes involved in N cycling pathways in the rhizosphere, including nitrification (amoA) and denitrification pathways (nirS, nirK, nosZ), can indicate $\mathrm{N}$ transformation rates and thus $\mathrm{N}$ availability to plants (Jarvis, 1989. Plants also benefit from direct associations with arbuscular mycorrhizal (AM) fungi for the uptake of water and low mobile nutrients, especially phosphorus (P), through extended mycorrhizal hyphae networks in soils (Bohm et al., 1996). These microbial processes can be accelerated or inhibited by different soil moisture patterns and wet-dry cycles induced by irrigation, thus regulating plant nutrient uptake and soil nutrient cycling (Bertrand et al., 2014; Zencich et al., 2002). However, in previous studies, responses of rhizosphere microbial processes to irrigation have attracted limited attention and are often considered separately from root developmental traits (Meng et al., 2020). This limits the mechanistic understanding the rootsoil- microbe interact and adapt to resource availability under different irrigation strategies.

The comparison between two-irrigation strategies system such as SDI and FI, was initiated in a 2year certified organic tomato (Solanum lycopersicum L.) and maize (Zea mays L.) rotation system since 2015. The comparison was established by splitting the experimental plot into two sides, with SDI treatment assigned to one side and FI to the other side Fig. (2) The experiment took place on three replicated plots in the processing tomato phase of the organic tomato-maize rotation in 2017 (i.e., 2 years after the initiation of irrigation comparison) (Wu et al., 2016).Processing tomato (variety: Heinz 8504 ) was transplanted as a single row on a $150 \mathrm{~cm}$ wide raised bed, and the planting density was 21,000 plants $\mathrm{ha}^{-1}$. SDI was implemented through a single drip line buried at the center of the bed $25 \sim 30 \mathrm{~cm}$ below the soil surface. FI was applied through surface flood irrigation, with alternate irrigation of the two furrows between each bed during the growing season as presented in Fig. (3a\&b). FI received $11,222 \mathrm{~m}^{-3} \mathrm{ha}^{-1}$ and SDI received $4,839 \mathrm{~m}^{-3} \mathrm{ha}^{-1}$ of irrigation during the 2017 growing season. The weekly irrigation schedule was derived from the irrigation recommendation of Tule (Tule Technologies, United States), which measures actual evapotranspiration (ET) of a field using the Surface Renewal method through in situ sensors (Wu et al., 2016). Tule provides weekly irrigation recommendations based on previous week's actual ET, plant responses, forecasted atmospheric demand, and the estimation of water demand depending on production goals. The frequency and volume of each irrigation events for FI and SDI was recorded using flow meters over the growing season. Composted poultry manure $\left(9 \mathrm{Mg} \mathrm{ha}^{-1}\right)$ contained approximately $20.0 \% \mathrm{C}, 2.0 \% \mathrm{~N}$, and $1.4 \% \mathrm{P}$ was applied prior to tomato planting. Both irrigation treatments received the same amount of composted manure but were applied differently: mixing with the top $20 \mathrm{~cm}$ of soils in the FI system and banding compost on top of the drip line in the SDI system Fig. (3a\&b).

Different application methods of composted manure are part of the long-term design of this experiment and implemented to maximize the overlap between fertilizer distribution and the specific moisture pattern of the two irrigation strategies. Winter cover crop was seeded with a mix of legumes and grass, composing of $90.0 \mathrm{~kg} \mathrm{ha}^{-1}$ bell bean (Vicia faba L.), $22.5 \mathrm{~kg} \mathrm{ha}^{-1}$ lana vetch (Vicia villosa Roth), and $28.0 \mathrm{~kg} \mathrm{ha}^{-1}$ oats (Avena sativa L.). Winter cover crop was terminated and incorporated into 
the soil before compost application and planting. Root Distribution and Analysis Tomato root distribution was characterized on fully developed root systems using detailed field soil profiles and digital analysis taken in both treatments 105 days after transplanting (i.e., 3 days after the irrigation ceased and 2 weeks prior to tomato harvest). To observe root distribution, we dug the soil trench manually using shovels and mattocks on a randomly selected crop row in each treatment. We smoothed the soil profile surface using a sharpshooter spade. The observation trench was $90 \mathrm{~cm}$ (length) $* 80 \mathrm{~cm}$ (width) $* 60 \mathrm{~cm}$ (depth). Root distribution was recorded on the soil profile surface perpendicular to the plant row and tangential to the plant stem. Root distribution were taken at $90 \mathrm{~cm}$ from the soil profile surface and digitally processed to extract root distribution and morphological trait data. The smartphone application CamScanner (IntSig Information Co., Ltd, China, version 5.1.2) was used to enhance the contrast and correct deformation. This method was previously tested and shown to provide high-quality images suited for root traits analysis (Wu et al., 2016). Processed images were converted to 8- bit gray images using the Fiji platform Wu et al., (2016) and imported into WinRHIZO software (Regent Instruments, Canada) for root analysis. Total root length and root diameters were obtained from each quadrat. Root distribution was calculated as the percentage of root length contained in each quadrat relative to the total root length.

Meng et al. (2020) observed that root distribution subsurface drip irrigation with banded compost resulted in a more concentrated root distribution pattern than the furrow irrigation with compost incorporated into topsoil. SDI was more a higher percentage of root length at the depth of $20-30 \mathrm{~cm}$, 10-20 $\mathrm{cm}$ away from the drip line than FI. Fig. (4).
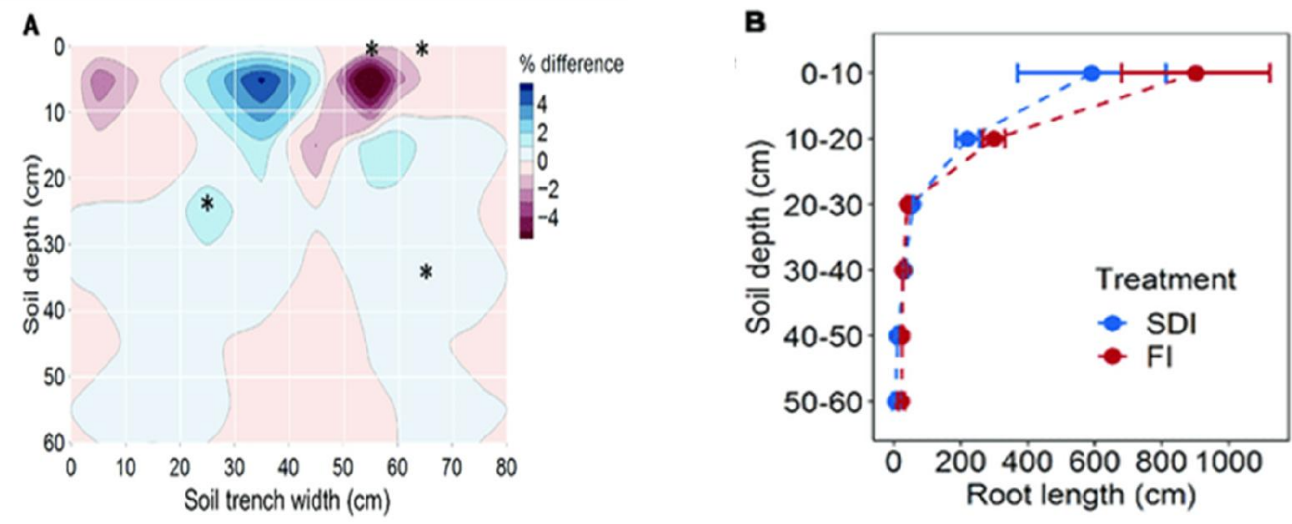

Fig. 4: Represents a diagram of root distribution under different irrigation systems subsurface drip irrigation (SDI) and furrow irrigation (FI). (A) Root distribution by position and (B) Root length at different soil depths of tomato plants after Meng et al., (2020).

Similarly, a higher percentage of root length was found at the depth of $30-40 \mathrm{~cm}, 20-30 \mathrm{~cm}$ away from the drip line in SDI than in the FI system. Conversely, FI led to higher root distribution toward the edge of the bed and at greater depth relative to SDI. A greater percentage of roots was found in the top $10 \mathrm{~cm}$ of soil and at $10-20 \mathrm{~cm}$ and $20-30 \mathrm{~cm}$ from the bed center in the FI than the SDI system. In addition, future studies in organic systems are needed to enhance root morphological and physiological plasticity, harness beneficial microbes for improved nutrient cycling, and optimize irrigation strategies that maximize the resource mining potential of roots and rhizosphere processes. These innovations will enhance the ability of agro ecosystems to better utilize biological processes rather than costly inorganic fertilizer and irrigation inputs and build up the resilience of agro ecosystems in the face of future climate change and resource shortages.

\section{Advantages and disadvantages of SDI}

The following list should be considered as potential advantages of subsurface drip irrigation (SDI) when properly managed and/or when site conditions and cropping systems allow the advantage to be realized. Additionally, some growers might see an aspect as an advantage, while another might see an aspect as a disadvantage. For example, there are opportunities for improved cultural practices with SDI, 
while at the same time; there might be fewer tillage alternatives. These advantages may be further subdivided along the lines of water and soil issues, cropping and cultural practices and system infrastructure issues.

\subsection{Advantages related to water and soil issues}

\subsubsection{More efficient water use}

Soil evaporation, surface runoff, and deep percolation are greatly reduced or eliminated. Infiltration and storage of seasonal precipitation can be enhanced by drier soils with less soil crusting. In some cases, the system can be used for a small irrigation event for use in germination, depending on dripline depth, flow rate and soil constraints. The inherent ability to apply small irrigation amounts can allow better water-- efficient decisions about irrigation events near the end of the cropping season. In widely spaced crops, a smaller fraction of the soil volume can be wetted, thus further reducing unnecessary irrigation water losses.

\subsubsection{Less water quality hazards}

Runoff into streams is reduced or eliminated, and there is less nutrient and chemical leaching due to deep percolation.

\subsubsection{Improved opportunities for use of degraded waters}

Smaller and more frequent irrigation applications can maintain a more consistent and lower soil matric potential that may reduce salinity hazards. Subsurface wastewater application can reduce pathogen drift and reduce human and animal contact with such waters.

\subsubsection{Greater water application uniformity}

Improved in-field uniformities can result in better control of the water, nutrients and salts. Widely spaced crops may benefit from water application closer to the crop, provided sufficient soil wetting is achieved.

\subsection{Advantages related to cropping and cultural practices}

\subsubsection{Enhanced plant growth, crop yield and quality}

A number of crops respond positively. Improved plant health, less disease and fungal pressure occurs due to drier and less-humid crop canopies. The system can also be used for some types of soil fumigation.

\subsubsection{Improved fertilizer and pesticide management}

Precise and more timely application of fertilizer and pesticides through the system can result in greater efficacy and, in some cases, reduction in their use.

\subsubsection{Better weed control}

Reductions in weed germination and weed growth often occur in drier regions

\subsubsection{Improved double cropping opportunities}

Crop timing may be enhanced since the system need not be removed at harvesting and reinstalled prior to planting the second crop.

\subsubsection{Improved farming operations and management}

Many field operations can occur during irrigation events. Field operations result in less soil compaction, and soil crusting caused by irrigation is greatly reduced. Variability in soil water regimes and redistribution are often reduced with SDI as compared to surface drip irrigation (DI). Additionally, weather-related application constraints such as high winds, freezing temperatures and wet soil surfaces are less important. Needed fertilization can be applied in a small irrigation event even when irrigation needs are low. The ability to irrigate during freezing conditions can be particularly beneficial where preseason irrigation is used to effectively increase seasonal irrigation capacity. There is also less irrigation equipment exposed to vehicular damage. Hand laborers benefit from drier soils by having reduced manual exertion and injuries. 


\subsection{Advantages related to system infrastructure}

\subsubsection{Automation}

The closed-loop pressurized characteristic of the system that can reduce application variability and soil water and nutrient redistribution variability make the system an ideal candidate for automation and advanced irrigation control technologies.

\subsubsection{Decreased energy costs}

Operating pressures are often less than some types of sprinkler irrigation. Any water savings attributable to SDI will also reduce energy costs.

\subsubsection{System integrity issues}

There are fewer mechanized parts in an SDI system as compared to mechanical-move sprinkler irrigation systems. Most components are plastic and are less subject to irrigation system corrosion. SDI systems do not need to be removed and installed between crops and, thus, can experience less damage. The potential for vandalism is also reduced.

\subsubsection{Design flexibility}

There is increased flexibility with SDI in matching field shape and field size as compared to center pivot sprinkler irrigation systems. The SDI system can be easily and economically sized to the available water supply. In widely spaced crops, driplines can be placed for optimum water and nutrient uptake. Pressure compensating SDI systems have fewer slope limitations than surface gravity irrigation.

\subsubsection{System longevity}

SDI installations can have a long economic life when properly designed and managed. Long system life allows for amortizing investment costs over many years, thus allowing lower-value commodity crops to be economically grown with SDI. Less pest damage - In some cases, there may be less pest damage to SDI systems from wildlife and insects than for DI systems. However, this must be tempered with the fact that pest damage to SDI systems may take more effort to detect and to repair.

\section{Disadvantages of SDI}

Similarly, there are circumstances and situations that present disadvantages to selection of an SDI system. These disadvantages also may be subdivided along the lines of water and soil issues, cropping and cultural practices, and system infrastructure issues.

\subsection{Disadvantages related to water and soil issues}

\subsubsection{Smaller wetting pattern}

The wetting pattern may be too small on coarse-textured soils, resulting in too small a crop root zone. This situation can make system capacity and system reliability extremely critical issues, as there is less ability to buffer insufficient irrigation capacity or system breakdown.

\subsubsection{Monitoring and evaluating irrigation events}

Water applications may be largely unseen, and it is more difficult to evaluate system operation and application uniformity. System mismanagement can lead to under irrigation and crop yield and quality reductions or over irrigation, resulting in poor soil aeration and deep percolation problems. Soil/Application rate interactions

Emitter discharge rates can exceed the ability of some soils to redistribute the water under normal redistribution processes. In such cases, water pressure in the region around the outside of the emitter may exceed atmospheric pressure, thus altering emitter flows. Water may inadvertently "surface" (tunneling of the emitter flow to the soil surface) causing undesirable wet spots in the field. In "surfacing" problems, small soil particles may be carried with the water, causing a "chimney effect," that provides a preferential flow path. The "chimney" may be difficult to permanently remove, since a portion of the "chimney" remains above the dripline even after tillage. 


\subsubsection{Reduced upward water movement}

Using the SDI system for germination may be limited, depending on installation depth and soil characteristics. This may be particularly troublesome on soils with vertical cracking. Salinity may be increased above the dripline, increasing the salinity hazard for emerging seedlings or small transplants.

\subsection{Disadvantages related to cropping and cultural practices}

\subsubsection{Less tillage options}

Primary and secondary tillage operations may be limited by drip line placement.

\subsubsection{Restricted plant root development}

Smaller crop root zones can make irrigation and fertilization more critical issues from both a timing and amount perspective. Smaller crop root zones may be insufficient to avoid diurnal crop water stresses even when the root zone is well watered. Application of nutrients through the SDI system may be required for optimum yields. Application of micronutrients may also become more important as the smaller soil volume becomes depleted of these nutrients sooner.

\subsubsection{Row spacing and crop rotation issues}

Since SDI systems are fixed spatially, it may be more difficult to accommodate crops of different row spacing. Some crops might require a very close dripline spacing that might be economically impractical. Additional care must be taken at the time of annual row-crop planting to ensure crop orientation and spacing are appropriately matched to the dripline location.

\subsubsection{Plant development issues}

Some crops may not develop properly under SDI in some soils and climates. Peanuts may not peg properly into dry soil. Tree crops may benefit from a larger wetting pattern.

\subsection{Disadvantages related to system infrastructure}

\subsubsection{Costs}

SDI has a high initial investment cost compared to some alternative irrigation systems. In many cases, the system has no resale value or a minimal salvage value. Lenders may require a higher equity level and more collateral before approving SDI system loans. Such large investments may not be warranted in areas with uncertain water and fuel availability, particularly if commodity price outlook is poor. SDI systems typically have a shorter design life than alternative irrigation systems, which means the annualized depreciation costs, must increase to provide for system replacement.

\subsubsection{Filtration issues}

As with all micro irrigation systems, water filtration is a critical issue in ensuring proper system operation and system longevity. However, the issue can become more critical for longterm SDI systems where a system life of greater than ten years is desired. SDI may require more complex water quality management than some surface micro irrigation systems, since there are no opportunities to manually clean emitters.

\subsubsection{Other maintenance issues}

Timely and consistent maintenance and repairs are a requirement. Leaks caused by rodents can be more difficult to locate and repair, particularly for deeper SDI systems. The driplines must be monitored for root intrusion, and system operational and design procedures must employ safeguards to limit or prevent further intrusion. Roots from some perennial crops may pinch driplines, eliminating or reducing flows. Periodically, the drip lines need to be flushed to remove accumulations of silt and other precipitates that may occur in the drip lines.

\subsubsection{Operational issues}

Operation and management requires more consistent oversight than some alternative irrigation systems. There are fewer visual indicators of system operation and of the system application uniformity. 
Irrigation scheduling procedures are required to prevent under irrigation and over irrigation. Monitoring of system flow meters and pressure gages are required to determine if the system is operating properly.

\subsubsection{Design issues}

SDI is a less-developed technology than some alternative irrigation systems. This is particularly so in some regions where growers have little exposure and experience with these systems. There are fewer turnkey systems available for purchase. In some regions, the lack of contractor capacity can result in inadequate timing of installations in wet periods. Design errors are more difficult to resolve since most of the SDI system is below ground. There are typically more components needed for SDI than DI systems. There is the possibility of soil ingestion at system shutdown if a vacuum occurs, so air relief/vacuum breaker devices must be present and operating correctly. As with any micro irrigation system, zone size and length of run will be limited by system hydraulics. Compression of the dripline due to soil overburden can occur in some soils and at some depths, causing adverse effects on flow. SDI systems are not typically well suited for Site Specific Variable Application.

\subsubsection{Abandonment issues}

In some cases, there are concerns about waste plastic product (driplines) in the subsoil if the SDI system is abandoned.

\subsubsection{Overlap of issues}

The subdivision of the advantages and disadvantages into the three categories - water and soil issues

- Cropping and cultural practices

- System infrastructure issues, is entirely arbitrary. However, it does allow for focusing on the conceptual issues of adoption of SDI. It is apparent that some issues also overlap between the three categories. A case could be made to look at a different subdivision emphasizing first the importance of system infrastructure issues. In this case, the disadvantages of SDI might break in a different manner with a preponderance of issues showing up in this group.

The revised system infrastructure group would include these nine disadvantages:

- Monitoring and evaluating irrigation events

- Application rate issues

- Less tillage options

- Costs

- Filtration

- Other maintenance issues

- Operational issues

- Design issues

- Abandonment issues.

Many of these nine disadvantages can be addressed through further design, research and development, a clear indication that they are often solvable problems. However, in some cases, solving the problem may make high investment costs become an even greater issue.

\section{Perspectives for subsurface drip irrigation}

Irrigation is the important key factor for sustaining food supply for increasing population in the world. The technical FAO study "World agriculture: towards 2015/2030" (FAO 2015) highlights that production of staple crops must follow the same increasing trend than in the last decades. Consequently, their productivity should increase and, thus irrigation will play an important role but it will have to accommodate the conditions of water scarcity and environmental and ecological sustainability. On the other hand, many areas in the world, as their economy develops, the urban activities expand increasing water demands and develop competing uses of limited water resources. Thus, it raises uncertainty whether the volume of water used in irrigated agriculture can be sustained. The use of new technologies and more efficient irrigation methods develop water conservation policies. Using of irrigation methodology that reduce water use and increasing yield production should be encouraged by farmers, in order to allow water to flow to other economic sectors. Consequently, subsurface drip irrigation (SDI) 
perspectives are promising, due to higher capability for minimizing the loss of water by evaporation, runoff, and deep percolation as compared with other methods. Furthermore leading to increase crop yields production, reducing water fluctuated in soil, which created well-aerated plan root zone. In addition, using of wastewaters treatments particularly in arid and semi-arid region with water scarcity could be used with risk assessments in human and animal health. Moreover, reducing the agrochemical treatments since its distributed within the roots zone. Therefore, subsurface irrigation (SDI) efficiency, in some irrigation scenarios, is better than other irrigation methods.

\section{Conclusion}

Micro irrigation shows indeed the major benefit of saving water but also, improving yields and crop quality. Subsurface drip irrigation $(S D I)$ is a relatively new system technique that may give higher crop yields while using less water than other irrigation systems. Technologies that ensure the availability of water for crops need to be developed in order for agriculture to be sustainable in the face of climate change. Irrigation is costly, so technologies need to be improved or newly developed, not only with the aim of the sustainable use of precious water resources, but also reducing labor and energy costs, which lead to higher production costs. Frequency of water irrigation improve surface wetting, although subsurface irrigation $(S D I)$ in practice, may increasing drainage, which appears to be related to increasing irrigation amount. Many tools have developed to accomplish the goals, other promising instruments and techniques will be soon available for the management of fertigated crops. This review will help you for field, soil, crop, cropping system, and irrigation water resources as they apply to subsurface irrigation $(S D I)$. Application of the innovative irrigation technologies was restrained due to the impact of negative factors, since most of these factors have a systemic nature, it is necessary beforehand to provide a package of preventive measures to ensure favorable conditions for a large-scale implementation of these technologies, including.

Root development and profile water uptake pattern varied with the irrigation method, major root zone in border-irrigated $(B I)$ field was the deepest, followed by the shallower in sprinkler-irrigated $(S I)$ field and the shallowest in surface drip-irrigated $(S D I)$ field. In addition, profile water uptake pattern was affected by soil water dynamics and root distribution. Due to the appropriate soil water and high root length density, the amount of uptake from the $0-50 \mathrm{~cm}$ depth was highest in surface drip-irrigated field. Because of the long-time water deficit in border irrigation treatment, it showed the lowest. Water uptake in depth of $(50-100) \mathrm{cm}$, under border irrigation was the highest among the three methods. Main root uptake zone moved downwards with the longtime water deficit in surface layer. At the same time, with the high soil water content and root density in the upper layer, the main water uptake zone was concentrated in the upper layer in sprinkler and surface drip-irrigated field.

Surface drip irrigation, root distribution and water uptake pattern changed as compared with the traditional border irrigation. The variation in quantity and distribution of root uptake would have great effects on water or nutrients dynamics. These innovations will enhance the ability of agro ecosystems to better utilize biological processes rather than costly inorganic fertilizer and irrigation inputs and build up the resilience of agro ecosystems in the face of future climate change and resource shortages.

\section{References}

Ali, M.H., 2011. Water application methods. In Practices of Irrigation and On-farm Water Management; Springer Science: Berlin, Germany, Volume 2.

Allen, R.G., L.S. Pereira, D. Raes and M. Smith, 1998. Crop evapotranspiration, guidelines for computing crop water requirements. FAO irrigation and drainage paper 56, Food and Agriculture Organization of the United Nations (FAO), Rome.

Allison, G., 1982. The relationship between $18 \mathrm{O}$ and deuterium in water in sand columns undergoing evaporation. J. Hydrol., 55: 163-169.

Antony E., and R.B. Singandhupe, 2004. Impact of drip and surface irrigation on growth, yield and WUE of capsicum (Capsicum annum L.) Agric. Water Manag. 65: 121-132.

ASAE, 2001. ASAE Standard S256.2 JAN 01. Soil and Water Terminology. American Society Agricultural Engineers. St. Joseph, Michigan, 21.

Atkinson, D., 1983. The growth, activity and distribution of the fruit tree root system. Plant Soil, 71: $23-35$. 
Atkinson, D. and S.A. Wilson, 1980. The growth and distribution of fruit tree roots: Some consequences for nutrient uptake. In Proceedings of the Acta Horticulturae ISHS: Symposium on Mineral Nutrition and Fruit Quality of Temperate Zone Fruit Trees, Canterbury, UK, 1-7 April, 92: 137150.

Batra, B.R., M. Inder, S.K. Arora, and I. Mohan, 2000. Effect of irrigation and nitrogen levels on dry matter production by okra (Abelmochus esculentus L.Moench). Haryana J. Hortic. Sci., 29 (3-4): 239-241.

Bertrand, G., J. Masini, N. Goldscheider, J. Meeks, V. Lavastre, H. Celle-Jeanton, J.M. Gobat, D. Hunkeler, 2014. Determination of spatiotemporal variability of tree water uptake using stable isotopes $(\delta 18 \mathrm{O}, \delta 2 \mathrm{H})$ in an alluvial system supplied by a high-altitude watershed, Pfyn forest, Switzerland. Ecohydrology, 7:319-333.

Bhattari, S.P., S. Huber, and D.J. Midmore, 2004. Aerated subsurface irrigation gives growth ad yield benefits to zucchini, vegetavle soybean and cotton in heavy clay soils. Ann. Appl. Biol., 144: 285298.

Black, B.L., D. Drost, T. Lindstrom, J. Reeve, J.D. Gunnell, and G.L. Reighard, 2010. A Comparison of root distribution patterns among prunus rootstocks. J. Am. Pomol. Soc., 64: 52-62.

Bryla, D.R., G.S. Banuelos, and J.P. Mitchell, 2003. Water requirements of subsurface drip irrigated faba bean in California. Irrig. Sci., 22: 31-37.

Bufon, V.B., R.J. Lascano, C. Bednarz, J.D. Booker, and D.C. Gitz, 2012. Soil water content on dripirrigated cotton: Comparison of measured and simulated values obtained with the Hydrus 2-D model. Irrig. Sci., 30: 259-273.

Cai G., J. Vanderborght, H. Vereecken, V. Couvreur, and C.M. Mboh, 2017. Parameterization of root water uptake models considering dynamic root distributions and water uptake compensation. Vadose Zo. J. DOI:10.2136/v zj2016.12.0125

Camp, C.R., 1998. Subsurface drip irrigation: a review. Trans ASAE. 41(5): 1353-1367.

Cancela J.J., M. Fandino, B. Rey, and E.M. Martinez, 2015. Automatic irrigation system based on dual crop coefficient, soil and plant water status for Viris vinifera (cv Godelloand cv Mencia). Agric. Water Manag., 151: 52-63.

Cao, X., P. Yang, A.E. Bernard, and P. Li, 2018. The effects of rainfall and irrigation on cherry root water uptake under drip irrigation. Agric. Water Manag. 197: 9-18.

Ceausescu, I., A. Negrila, I. Isac, and A. Lazar, 1982. Fruit Growing; Publishing House Ceres: Bucharest, Romania, (In Romanian)

Coelho, E.F., and D. Or, 1999. Root distribution and root water uptake patterns of corn under surface and subsurface drip irrigation. Plant and Soil. 206:123-136.

Costa, D.L., and G. Gianquinto, 2002. Water stress and water table depth influence yield, water use efficiency and nitrogen recovery in bell pepper, lysimeters studied. Australian J. Agric. Res., 53: 201-210.

Cote, C.M., K.L. Bristow, P.B. Charlesworth, F.J. Cook, and P.J. Thorburn, 2003. Analysis of soil wetting and solute transport in subsurface trickle irrigation. Irrig. Sci., 22: 143-156.

Dawson, T.E., and J.S. Pate, 1996. Seasonal water uptake and movement in root systems of Australian phraeatophytic plants of dimorphic root morphology: A stable isotope investigation. Ecology, 107: 13-20.

DeMalach, Y., and D. Pasternak, 1993. Agriculture in a desert saline environment, a case study. In MaraniBettolo, G.B. (Ed.). Agriculture and the Quality of Life, New Global Trends. Proceeding of an international conference held at The Pontificia Academia Scientiarum, Ex Aedibvs Academicis in Civitate Vaticana, Rome, Italy, 97-26.

Dexter, A.R., 2004. Soil physical quality: Part I. Theory, effects of soil texture, density, and organic matter, and effects on root growth. Geoderma, 120(3-4):201-214.

Doorenbos J., W.O. Pruitt, A. Aboukhaled, and J. Damagnez, 1992. Crop water requirements; FAO Irrigation and Drainage paper 24. Food and Agriculture Organization of the United Nations, Rome.

Du, T., S. Kang, and J. Zhang, 2011. Water-saving and crop quality improvement of alternate partial root-zone irrigation and application of isotope technology in the research of crop water use. Chin. J. Plant Physiol. J., 47: 823-830.

Ehlers, W., and A.P. Hamblin, 1991. Tennant, D. Root system parameters determining water uptake of field crops. Irrig. Sci., 12: 115-124. 
El-Nesr, M.N., A.A. Alazba, and J. Šimůnek, 2014. HYDRUS simulations of the effects of dual-drip subsurface irrigation and a physical barrier on water movement and solute transport in soils. Irrig. Sci. 32: 111-125.

Evans, R.G., I. Wu, and A.G. Smajstrala, 2007. Microirrigation Systems. In Design and Operation of Farm Irrigation Systems; Hoffman, G.J., Evans, R.G., Jensen, M.E., Martin, D.L., Elliott, R.L., Eds., American Society of Agricultural and Biological Engineers: St. Joseph, MI, USA, Chapter, 17: 632-679.

Fandino, M., J.J. Cancela, B.J. Rey, E.M. Martibez, R.G. Rosa, and L.S. Pereire, 2012. Using the dual Kc approach to model evapotranspiration of Albarino vineyards (Viris vinifera L. cv. Albarino) with consideration of active ground cover. Agric. Water Manag. 112: 75-87.

FAO, 2015. Towards a water and food secure future; Critical perspective for policy makers. FAO White paper. Food and Agriculture Organization of the United Nations, Rome and World Water Council, Marseille.

FAO. Status and trends in land and water resources, 2011. In The State of the World's Land and Water Resources for Food and Agriculture (SOLAW): Managing Systems at Risk; Routledge: London, UK, Chapter, 1: 19-62.

Fares, A., L.R. Parsons, T.A. Wheaton, K.T. Morgan, J. Šimůnek, and M.Th. van Genchuten, 2001. Simulated drip irrigation with different types of soils. Proc Fla State Hort Sci., 114:22-24.

Feddes R.A., H. Hoff, M. Bruen, T. Dawson, P. de Rosnay, P. Dirmeyer, R.B. Jackson, P. Kabat, A. Kleidon, A. Lilly, and A.J. Pitman, 2001. Modeling root water uptake in hydrological and climate model. Am. Meteorological Soc., 82 (12): 2797-2810.

Ferrara A., S. Lovelli, T. Di Tommaso, and M. Perniola, 2011. Flowering, growth and fruit setting in greenhouse bell pepper under water stress. J. Agro., 10: 12-19.

Flanagan, L., and J. Ehleringer, 1991. Stable isotope composition of stem and leaf water: Applications to the study of plant water use. Funct. Ecol., 5: 270-277.

Gärdenäs, A.I., J.W. Hopmans, B.R. Hanson, and J. Šimůnek, 2005. Two-dimensional modeling of nitrate leaching for various fertigation scenarios under micro-irrigation. Agric. Water Manag. 74: 219-242.

Ghazouani, H., B.D. M'hamdi, D. Autovino, A.M. Mguidiche Bel Haj, G. Rallo, G. Provenzano, and A. Boujelben, 2015. Optimizing subsurface dripline installation depth with Hydrus 2D/3D to improve irrigation water use efficiency in the central Tunisia. Int. J. Metrol. Qual. Eng., 6: 1-9.

Gli 'nski, J., J. Lipiec, and W. Stepniewski, 2008. Plant Roots and Soil Physical Factors; Chesworth, W., Ed., Encyclopedia of Soil Science; Springer: Berlin/Heidelberg, Germany, Lipiec, J., Nosalewicz, A., Pietrusiewicz, J. 2011 Crop Responses to soil physical conditions. In Encyclopedia of Agrophysics; Gli 'nski, J., Horabik, J., Lipiec, H., Eds., Springer: Dordrecht, The Netherlands; Heidelberg, Germany; London, UK; New York, NY, USA.

Hanson, B., J.W. Hopmans, and J. Šimůnek, 2008. Leaching with subsurface drip irrigation under saline, shallow ground water conditions. Vadose Zo. J., 7(2): 810-818.

Hanson, B.R., J. Šimůnek, and J.W. Hopmans, 2006. Evaluation of urea-ammonium-nitrate Fertigation with drip irrigation using numerical modeling. Agric. Water Manag. 86: 102-113.

Hanson, B.R., 1995. Drip irrigation of row crops: An overview. In: Proceedings Fifth International Microirrigation Congress, Orlando, FL, April 2-6: 651-655.

Hillel, D., 1980. Applications of soil physics. Academic Press Inc. New York.

Imanudin, M.S and Prayitno, 2015. Pengembangan irigasi bawah pemukaan untuk irigasi mikro melalui metoda kapilaritas tanah. Proceeding Seminar of Swasembada Pangan. 29 April 376-381 (In Indonesian).

IPCC. Food security and food production systems. In Climate Change, 2014. Impacts, Adaptation, and Vulnerability. Working Group II Contribution to the Fifth Assessment Report of the Intergovernmental Panel on Climate Change; Technical Report for Cambridge University Press: Cambridge, UK; New York, NY, USA, Chapter, 7: 485-534.

Ityel, E., N. Lazarovitch, M. Silberbush, and A. Ben-Gal, 2011. An artificial capillary barrier to improve root zone condition for horticultural crops: physical effects on water content. Irrig. Sci., 29: 171180. 
Jarvis, N.J., 1989. A simple empirical model of root water uptake. Hydrol. J. 107; 57-72. Ju S.H., Kung K.J.S., 1997. Mass types, element orders and solution schemes for Richards's equation Comp. Geosci. 23(2): 175-187.

Kandelous, M. M., J. Šimůnek, M.Th. van Genuchten and K. Malek, 2011. Soil water content distributions between two emitters of subsurface drip irrigation system. Soil Sci. Soc. Am. J., 75: 488-497.

Kandelous, M.M., and J. Simunek, 2010. Numerical simulations of water movement in a subsurface drip irrigation system under field and laboratory conditions using HYDRUS. Agric. Water Manag. 97: 1070-1076.

Kolesnikov, V., 1971. The Root System of Fruit Plants; Mir Publishers: Moscow, Russia.

Kreij, D.C., A.M.M. van der Burg, and W.T. Runia, 2003. Drip irrigation emitter clogging in Dutch greenhouses as affected by methane and organic acids. Agric. Water Manag. 60 (2): 73-85

Krounbi, L., and N. Lazarovitch, 2011. Soil hydraulic properties affecting root water uptake. In: J. Gliński et al., editors, Encyclopedia of gro-physics. Springer, Dordrecht, the Netherlands, 748-754.

Lamm, F.R., J.E. Ayars, and F.S. Nakayama, 2007. Micro irrigation for crop production; Design, Operation and Management. First Edition, Elsevier. B.V. The Netherland.

Lazarovitch, N., A.W. Warrick, A. Furman, and J. Šimůnek, 2007. Subsurface Water Distribution from Drip Irrigation Described by Moment Analyses. Vadose Zo. J., 6: 116.

Lazarovitch. N., U. Shani, T.L. Thompson, and A.W. Warrick, 2006. Soil Hydraulic Properties Affecting Discharge Uniformity of Gravity-Fed Subsurface Drip Irrigation Systems. J. Irrig. Drain. Eng., 132 (6): 531-536.

Li, J., Chen, L., Y. Li, and Y. Liu, 2008. Field Evaluation of Emitter Clogging in Subsurface Drip Irrigation Systems. In Proceedings of the ASABE Annual International Meeting, Providence, RI, USA, 29 June-2 July.

Lila, A.T.S., R. Berndtsson, M. Persson, M. Somaida, M. El-Kiki, Y. Hamed, and A. Mirdan, 2013. Numerical evaluation of subsurface trickle irrigation with brackish water. Irrig. Sci., 31: 1125-1137.

Martin, D.L., Heermann, D.F., and M. Madison, 2007. Hydraulics of sprinkler and Microirrigation systems. In Design and Operation of Farm Irrigation Systems; Hoffman, G.J., Evans, R.G., Jensen, M.E., Martin, D.L., Elliott, R.L. Eds., American Society of Agricultural and Biological Engineers: St. Joseph, MI, USA, Chapter, 15:532-556.

Martines J., and J. Reca, 2014. Water use efficiency of surface drip irrigation versus an alternative subsurface drip irrigation method. J. Irrig. And Drain. Eng., 140.

Meng, L., E.S. Jennifer, G.L. Deirdre, L. Patricia, K. Angela, B.M. Megan, M.S. Kate and C.M.G. Amelie, 2020.Impact of irrigation strategies on tomato plant root distribution and rhizosphere processes in an organic system Plant Sci., 11(360):1-12

Miguel, A., and M. Fransisco, 2007. Response of tomato plants to deficit irrigation under surface and subsurface drip irrigation. J. App. Hortic., 9(2): 97-100.

Mikkelsen, R., T.K. Hartz, and M.J.M. Rusan, 2015. Challenges of increasing water and nutrient efficiency in irrigated agriculture. In Managing Water and Fertilizer for Sustainable Agricultural Intensification, 1st ed., Drechsel, P., Heffer, P., Magen, H., Mikkelsen, R., Wichelns, D., Eds., International Fertilizer Industry Association(IFA), International Water Management Institute (IWMI), International Plant Nutrition Institute (IPNI) and International Potash Institute (IPI): Paris, France, Chapter 8; pp. 168-186.

Miyazaki, T., S. Hasegawa, and T. Kasubuchi, 1993. Water flow in soils. Marcel Dekker Inc. New York. Mommer L., and Visser E., "Protocol; Root distribution in soils I. Root core sampling and destructive pot harvests", was accessed 11/12/2017 at http://prometheuswiki.org /tikiindex.php? Page=Root + distribution + in + soils + I. + Root + core + sampling + destructive + pot + har vest

Nagazawa, K., J. Zhang, T. Nishimura, H. Saito, and M. Kato, 2008. Impact of pressure heads applied to porous bottles on water supply characteristics for subsurface irrigation. J. Arid Land Studies. 18(1): 11-20.

Oron, G., Y. DeMalach, L. Gillerman, and I. David, 1995. Pear response to saline water application under subsurface drip irrigation. In: Proceedings Fifth International Microirrigation Congress, Orlando, FL, April 2-6: 97-103. 
Oskamp, J., and L.P. Batjer, 1932. Soils in Relation to Fruit Growing in New York. II. Size, Production and Rooting Habit of Apple Trees on Different Soil Types in the Hilton and Morton Areas, Monroe County; Cornell University Agricultural Experiment Station: Ithaca, NY, USA.

Palada, M., A.C. Mercado, M. Roberts, V.B. Ella, M.R. Reyes, A.D. Susila, D.T. Ha, D.L. Wu, and M. Bhattarai, 2011. Farmers experiences with low-pressure drip irrigation for vegetable production in Southeast Asia and the Pasific. Acta. Hortic. 921: 49-56.

Paltineanu, C., L. Septar, C. Gavat, E. Chitu, M. Iancu, A. Oprita, C. Moale, G. Lamureanu, I. Calciu, V.M. Stroe, 2015. Spatial distribution of apricot roots in a semi-arid environment. Agrofor. Syst., 90: 469-478.

Paltineanu, C., L. Septar, C. Gavat, E. Chitu, A. Oprita, C. Moale, I. Calciu, O. Vizitiu, and G. Lamureanu, 2016. Characterizing Root density of peach trees in a semi-arid chernozem to increase plant density. Int. Agrophys, 30: 67-74.

Parker, M.L., and J.R. Meyer, 1996. Peach tree vegetative and root growth respond to orchard floor management. Hortscience, 31: 330-333.

Patel, N. and T.B.S. Rajput, 2008. Dynamic and modeling of soil water under subsurface drip irrigated onion. Agric. Water Manag. 95: 1335-1349.

Payero, J.O., C.D. Yonts, and S. Irmak, 2007. Advantages and Disadvantages of Subsurface Drip Irrigation; Nebraska Extension, Institute of Agriculture and Extension, University of NebraskaLincoln: Lincoln, NE, USA, 2005. Lamm, F.R., Camp, C.R. Subsurface drip irrigation. In Micro Irrigation for Crop Production-Design, Operation and Management; Lamm, F.R., Ayars, J.E., Nakayama, F.S., Eds., Elsevier: Amsterdam, the Netherlands, 2007; Chapter, 13: 473-551.

Phene, C.J., K.R. Davis, R.B. Hutmacher, B. Bar-Yosef, D.W. Meek, and J. Misaki,1991. Effect of high frequency surface and subsurface drip irrigation on root distribution of sweet corn. Irrig Sci., 12:135-140.

Phene, C.J., K.R. Davis, R.B. Hutmacher, B. Bar-Yosef, and D.W. Meek, 1990. Effect of high frequency surface and subsurface drip irrigation on root distribution of sweet corn. Irrig. Sci. J., 12: 135-140.

Phene, C.J., K.R. Davis, R.B. Hutmacher, and R.L. McCormic, 1987. Advantages of subsurface irrigation for processing tomatoes. In: Proceedings, International Symposium on Integrated Management Practices for Tomato and Pepper Production in the Tropics, Shanhua, Taiwan, ROC, 325-338.

Provenzano, G., 2007. Using HYDRUS-2D simulation model to evaluate wetted soil volume in subsurface drip irrigation systems. J. Irrig Drain Eng. ASCE 133(4):342-349.

PSDA (Direktorat Pengelolaan Sumber Daya Air; Directorate General of Water Resources), 2008. Pedoman teknis pengembangan irigasi bertekanan (Manual book of low-pressure irrigation; drip and sprinkler irrigation). pp 42 (In Indonesian). PU (Kementrian Pekerjaan Umum: Minstry of Public Work), 2016. Irigasi mikro. Available in http://litbang.pu.go.id/berita/view/814/air-mahalterapkan-irigasi-mikro. (accessed in 17 January 2018)

Purwartini, T.B. and R.N. Suhaeti, 2017. Small-scale irrigation: performance, problems and solutions. Forum Penelitian Agro Ekonomi 35(2): 91-105. (In Indonesian with English Abstract). DOI: 10.21082/fae.v35n2.2017.91-105.

Radin, J.W., J.R. Mauney, and P.C. Kerridge, 1989. Water uptake by cotton roots during fruit filling in relation to irrigation frequency. Crop Sci., 29:1000-1005.

Rawlins, S.L., and P.A.C. Roats, 1975. Prospects for high-frequency irrigation. Science 188:604-610

Roudier, P., B. Sultan, P. Quirion, and A. Berg, 2011. The impact of future climate change on West African crop yields: What does the recent literature say? Glob. Environ. Change, 21: 10731083

Saefuddin, R., H. Saito, and J. Šimůnek, 2018. Experimental and numerical evaluation of ring-shaped emitter for subsurface irrigation. Agric. Water Manag. 211: 111-122.

Saefuddin, R., B.I. Setiawan, S.K. Saptomo, and P.R.D. Mustaningsih, 2014. Performance Analysis of Emitter Ring Irrigation System. Jurnal Irigasi. 9: 63-74 (in Indonesian with English Abstract). https://doi.org/10.13140/RG.2.1.1102.6647

Sagi., 2006. Dripper resistance to clogging with use of effluent water; a case study. Int. Water Irrig. 26 (2): $42-43$

Shani, U., S. Xue, R. Gordin-Katz, and A. W.Warrick, 1996. Soil limiting flow from subsurface emitters. I: Pressure measurements. J. Irrig. Drain. Eng., 122(5): 291-295. 
Sharma, B., D. Molden, and S. Cook, 2015. Water use efficiency in agriculture: Measurement, current situation and trends. In Managing Water and Fertilizer for Sustainable Agricultural Intensification, 1st ed., Drechsel, P., Heffer, P., Magen, H., Mikkelsen, R., Wichelns, D., Eds., International Fertilizer Industry Association (IFA), International Water Management Institute (IWMI), International Plant Nutrition Institute (IPNI) and International Potash Institute (IPI): Paris, France, Chapter, 3: 39-64.

Shi, H., S. Liu, and X. Zhao, 2003. Application of stable hydrogen and oxygen isotope in water circulation. Chin. J. Soil Water Conserv., 17: 163-166.

Siedel, S.J., N. Schutze, M. Fahle, J.C. Mailhol, and P. Ruelle, 2015. Optimal irrigation scheduling, irrigation control and drip line layout to increase water productivity and proit in subsurface dripirrigated agriculture. J. Irrig. Drain, 64: 501-518.

Siemens, J., G. Huscheka, C. Siebe, and M. Kaupenjohanna, 2008. Concentrations and mobility of human pharmaceuticals in the world's largest wastewater irrigation system, Mexico City Mezquital Valley. Water Res., 42: 2124-2134.

Simionesei, L., T.B. Ramos, B. David, E. Jauch, and C.L. Pedro, 2016. Numerical Simulation of soil water dynamics under stationary sprinkler irrigation with MOHID-LAND. J. Irrig. And Drain, DOI: 10.1002/ird.1944.

Simunek, J., M. Sejna, H. Saito, M. Sakai, M.Th. van Genuchten, 2008. The HYDRUS-1D software package for simulating the one-dimensional movement of water, heat, and multiple solutes in variably saturated media, Version 4.0x, Hydrus Series 3. Department of Environmental Sciences, University of California Riverside, Riverside

Šimůnek, J., 2005. Models of water flow and solute transport in the unsaturated zone. In: MG Handerson (ed) Encyclopedia of Hydrol Sci., 1171-1180.

Šimůnek, J., and J.W. Hopmans, 2009. Modeling compensated root water uptake and nutrient uptake. Ecol. Modelling, 220: 505-521.

Šimůnek, J., M. Sejna, and M.Th. van Genuchten, 1999. The HYDRUS-2D software package for simulating two-dimensional movement of water, heat and multiple solutes in variably saturated media, Version 2.0. Rep. IGCWMC-TPS-53, p 251, International Ground Water Model. Cent., Colo. Sch. of Mines, Golden, CO.

Šimůnek J., and M.Th. van Genuchten, 2008. Modeling non-equilibrium flow and transport with HYDRUS. Vadose Zo. J., 7(2): 581-586.

Šimůnek, J., M.Th. van Genuchten, and M. Šejna, 2006. The HYDRUS software package for simulating two-, and three-dimensional movement of water, heat and multiple solutes in variably saturated media, Technical manual, Version 1.0, PC Progress, Prague, Czech Republic, 241.

Šimůnek, J., M.Th. van Genuchten, and M. Šejna, 2012. Hydrus: model use, calibration and validation. Tansac Asabe, 55(4): 1261-1274.

Šimůnek, J., M. Šejna, and M.Th. van Genuchten, 2018. New features of version 3 of the HYDRUS (2D/3D) computer software package. J. Hydrol. Hydromech, 66(2): 133-142.

Šimůnek, J., M.Th. van Genuchten, and M. Šejna, 2016. Recent developments and applications of HYDRUS computer software packages. Vadose Zo. J. 6: 1-25.

Siyal, A.A., M.T. van Genuchten, and T.H Skaggs., 2009. Performance of pitcher irrigation system. Soil Sci. 174: 312-320.

Strelkoff, T.S., and A.J. Clemmens, Hydraulics of surface systems, 2007. In Design and Operation of Farm Irrigation Systems; Hoffman, G.J., Evans, R.G., Jensen, M.E., Martin, D.L., Elliott, R.L., Eds., American Society of Agricultural and Biological Engineers: St. Joseph, MI, USA, Chapter, 13: 436-498.

Su D., Y. Tian, and Q.Z. Gao, 2000. Application of gravity and low head drip irrigation techniques in solar greenhouses." Trans. Chinese Soc. Agric. Eng. 16: 73-76 in Chinese with English abstract.

Sumarsono, J., B.I. Setiawan, I.D.M. Subrata, R.S.B. Waspodo, and S.K. Saptomo, 2018. Ring-typed emitter subsurface irrigation performances in dry land farming. Int. J. Civ. Eng. Technol. 9: 798806.

Sun, S.M., Q.X. An, P.L. Yang, X.B. Lu, and K.K. GU, 2016. Effect of irrigation depth on root distribution and water use efficiency of jujube under indirect subsurface drip irrigation. J. Trans. Chinese Soc. Agric. Machinery. 47 (8): 81-90. 
Sun, S., J. Huang, G. Lin, W. Zhao, and X. Han, 2005. Application of stable isotope technique in the study of plant water use. Chin. J. Acta Ecol. Sin., 25: 2362-2371.

Thorburn, P.J., and J.R. Ehleringer, 1995. Root water uptake of field-growing plants indicated by measurements of natural-abundance deuterium. Plant Soil, 177: 225-233.

Van Lier, H.N., L.S. Pereira, F.R. Steiner, CIGR, 1999. Handbook of Agricultural Engineering. Am. Soc. Agric. Eng., 1: 297-369.

Vazifedousta M., J.C. van Dam, R.A. Feddes, and M. Feizi, 2008. Increasing water productivity of irrigated crops under limited water supply at field scale. Agric. Water Manag. 95 (2): 89-102.

Wang, P., X. Song, D. Han, Y. Zhang, and X. Liu, 2010. A study of root water uptake of crops indicated by hydrogen and oxygen stable isotopes: A case in Shanxi Province, China. Agric. Water Manag. 97: 475-482.

Warrick, A.W., and U. Shani, 1996. Soil-limiting flow from subsurface emitters. II: Effect on uniformity.” J. Irrig. Drain. Eng. 122(5): 296-300.

Webber, H., T. Gaiser, and F. Ewert, 2014. What role can crop models play in supporting climate change adaptation decisions to enhance food security in Sub-Saharan Africa? Agric. Syst. 127: 161-177.

Wu, Y., T. Du, F. Li, S. Li, R. Ding, and L. Tong, 2016. Quantification of maize water uptake from different layers and root zones under alternate furrow irrigation using stable oxygen isotope. Agric. Water Manag. 168: 35-44.

Xi B., Y. Wang, M. Bloomberg, G. Li, and N. Di, 2013. Characteristic of fine root system and water uptake in a triploid Populus tomentosa plantation in the North Cina plain: Implications for irrigation water management. Agric. Water Manag. 117: 83-92.

Xu, F., Y.S. An, H. Li, Z.X. Guo, J.S. Li, and W.C. Li, 2004. Clogging of emitter in subsurface drip irrigation system. J. Transactions of the CSAE., 20 (1): 80-83

Xu, F., W. Li, J.S. Li, Y.S. Fan, and J.J. Feng, 2003. Hydraulic characteristics of emitter in soil of subsurface drip irrigation system. J. Transactions of the CSAE., 19 (1): 85-88

Yang, S., H. Liu, Z. Hao, and W. Wu, 2009. Spatial distribution characteristics of cherry tree roots under border irrigation condition. Chin. J. Tran. CSAE, 25 (Suppl. 1): 34-38.

Yano, K., N. Sekiya, B.K. Samson, M. Mazid, A. Yamauchi, Y. Kono, and L.J. Wade, 2006. Hydrogen isotope composition of soil water above and below the hardpan in a rainfed low land rice field. Field Crops Res. 96: 477-480.

Yao, S., I.A. Merwin, and M.G. Brown, 2009. Apple root growth, turnover, and distribution under different orchard groundcover management systems. Hortscience, 44: 168-175.

Zencich, S.J., R.H. Froend, J.V. Turner, and V. Gailitis, 2002. Influence of groundwater depth on the seasonal sources of water accessed by Banksia tree species on a shallow, sandy coastal aquifer. Ecology, 131: 8-19.

Zwart, S.J.Z., and W.G.M. Bastiaanssen, 2004. Review of measured crop water productivity values for irrigated wheat, rice, cotton and maize. Agric. Water Manag. 69 (2):115-133. 